Check for updates

Cite this: RSC Adv., 2019, 9, 18027

Received 2nd April 2019

Accepted 3rd June 2019

DOI: $10.1039 / \mathrm{c} 9 \mathrm{ra} 02467 \mathrm{k}$

rsc.li/rsc-advances

\title{
Research progress in the development of organic small molecule fluorescent probes for detecting $\mathrm{H}_{2} \mathrm{O}_{2}$
}

\author{
Yuanyuan Liu, abcd Chunpeng Jiao, ${ }^{\text {abcd }}$ Wenjuan Lu, ${ }^{\text {bcd }}$ Pingping Zhang ${ }^{\text {bcd }}$ \\ and Yanfeng Wang (iD) *bcd
}

Hydrogen peroxide $\left(\mathrm{H}_{2} \mathrm{O}_{2}\right)$, as an important signaling molecule during biological metabolism, is a key member of the reactive oxygen species (ROS) family. The excess of $\mathrm{H}_{2} \mathrm{O}_{2}$ will lead to oxidative stress, which is a crucial factor in the production of various ROS-related diseases. In order to study the diverse biological roles of $\mathrm{H}_{2} \mathrm{O}_{2}$ in cells and animal tissues, many methods have been developed to detect $\mathrm{H}_{2} \mathrm{O}_{2}$. Recently, fluorescence imaging has attracted more and more attention because of its high sensitivity, simple operation, experimental feasibility, and real-time online monitoring. Based on the response group, this study will review the research progress on hydrogen peroxide and summarizes the mechanisms, actualities and prospects of fluorescent probes for $\mathrm{H}_{2} \mathrm{O}_{2}$.

\section{Introduction}

In the oxygen-containing metabolism process, the living organism produces a variety of free radicals and derivatives with redox activity, ${ }^{\mathbf{1}, 2}$ and reactive oxygen species (ROS) are one of them. Reactive oxygen species includes superoxide $\left(\mathrm{O}_{2}{ }^{-}\right)$, hydroxyl radical $(\cdot \mathrm{OH})$, hydrogen peroxide $\left(\mathrm{H}_{2} \mathrm{O}_{2}\right)$, hypochlorous acid ( $\mathrm{HOCl})$ and so on, and their initial active substance is $\mathrm{O}_{2}{ }^{-}$. In living organisms, $\mathrm{O}_{2}{ }^{-}$is the basis for the formation of other reactive oxygen species., ${ }^{3,4}$ As is shown in Fig. 1, oxygen is catalyzed by NADPH (nicotinamide adenine dinucleotide phosphate) oxidase (NOX) to form $\mathrm{O}_{2}{ }^{-}$via single electron reduction. ${ }^{5,6}$ Subsequently, the two $\mathrm{O}_{2}{ }^{-}$are capable of forming $\mathrm{H}_{2} \mathrm{O}_{2}$ under the action of superoxide dismutase (SOD).$^{7-9} \mathrm{H}_{2} \mathrm{O}_{2}$ is converted to $\cdot \mathrm{OH}$ in the presence of a single electron metal ion such as $\mathrm{Fe}^{2+}$ undergoing Fenton reaction, and interacts with $\mathrm{Cl}^{-}$to form $\mathrm{HOCl}$ in the presence of myeloperoxidase (MPO).$^{10-12}$ As shown in the figure, when reacting with $\mathrm{O}_{2}{ }^{-}$, $\mathrm{HOCl}$ can convert into $\cdot \mathrm{OH}$ further. ${ }^{5,13}$ Arginine reacts with various nitric oxide synthase (NOS) enzymes to produce nitric oxide (NO), which reacts with $\mathrm{O}_{2}{ }^{-}$to produce peroxynitrite $\left(\mathrm{ONOO}^{-}\right){ }^{\mathbf{1 4 - 1 7}}$ Peroxynitrite can decompose to form hydroxyl radicals by interaction with hydrogen ions $\left(\mathrm{H}^{+}\right)$.

${ }^{a}$ School of Medicine and Life Sciences, University of Jinan-Shandong Academy of Medical Sciences, Jinan 250200, Shandong, China

${ }^{b}$ Institute of MateriaMedica, Shandong Academy of Medical Sciences, Jinan 250062, Shandong, China. E-mail:wyfshiwoya@126.com

'Key Laboratory for Biotech-Drugs Ministry of Health, Jinan 250062, Shandong, China ${ }^{d}$ Key Laboratory for Rare \& Uncommon Diseases of Shandong Province, Jinan 250062, Shandong, China
$\mathrm{H}_{2} \mathrm{O}_{2}$ in cells is mainly derived from mitochondria, endoplasmic reticulum (ER) and various oxidases. ${ }^{18-21}$ Among the above sources, protein-type oxidase plays a critical role in generating $\mathrm{H}_{2} \mathrm{O}_{2}$ for signal conversion purposes. $\mathrm{H}_{2} \mathrm{O}_{2}$, one of the key members of the ROS family, has a certain regulatory effect on many physiological processes of organisms. ${ }^{22,23}$ First, $\mathrm{H}_{2} \mathrm{O}_{2}$ is relevant to cell migration, proliferation and differentiation. Second, $\mathrm{H}_{2} \mathrm{O}_{2}$ has an immense influence on angiogenesis and vascular diameter regulation. Third, $\mathrm{H}_{2} \mathrm{O}_{2}$ can reversibly oxidize the proteins involved in the reaction, thereby activating or deactivating the pathway. In addition, it can effectively regulate the body's immune defence mechanism. For example, NADPH in neutrophils produces $\mu \mathrm{M}$-grade $\mathrm{H}_{2} \mathrm{O}_{2}$ to kill pathogens. ${ }^{24}$ Finally, $\mathrm{H}_{2} \mathrm{O}_{2}$ is closely connected with oxidative stressassociated cancers. In the case of oxidative stress, the concentration of $\mathrm{H}_{2} \mathrm{O}_{2}$ will increase to 10-15 $\mu \mathrm{M}$, which will further aggravate the condition of vasodilation cancer. ${ }^{25}$

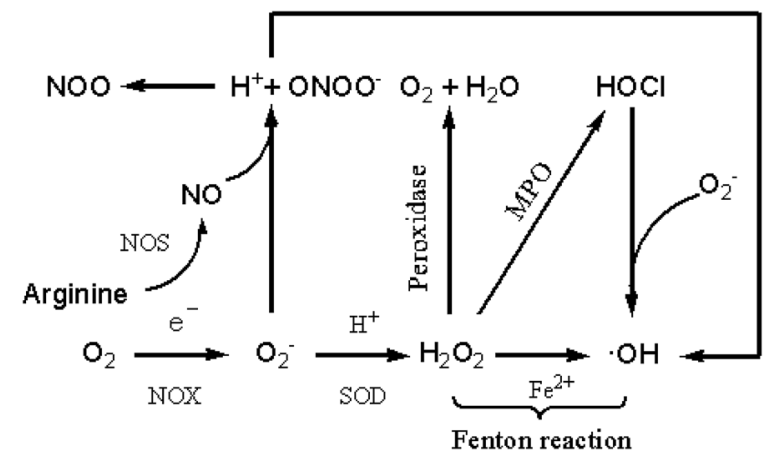

Fig. 1 The interaction between $\mathrm{H}_{2} \mathrm{O}_{2}$ and other ROS. 
As a vital signal molecule in the process of biological metabolism, hydrogen peroxide is attracting more and more attention for its ideal signal characteristics. First, it has adequate chemical reactivity to react with potential signal targets, and has sufficient stability to diffuse within the cell for a certain distance to react with the target selectively. ${ }^{26}$ Moreover, it can be generated rapidly, diffused and eliminated quickly, which makes it suitable as a signal generating substance. Normally, the average concentration of $\mathrm{H}_{2} \mathrm{O}_{2}$ in healthy mammalian cells ranges from 1 to $700 \mathrm{nM}$, and this low concentration of homeostasis is beneficial for normal cell growth. High concentrations of $\mathrm{H}_{2} \mathrm{O}_{2}$ can contribute to oxidative stress in the biological system and trigger apoptosis. ${ }^{27}$ Excessive accumulation of hydrogen peroxide in the human body can cause a series of inflammations and diseases, such as cancers, ${ }^{28}$ Alzheimer's disease $^{29}$ and cardiovascular diseases ${ }^{30}$ and also affects early embryological development in mammals. $\mathrm{H}_{2} \mathrm{O}_{2}$ is mainly used as a bleaching agent and disinfectant in life and plays an irreplaceable and indispensable role in the living system.

At present, studying the dynamic distribution of $\mathrm{H}_{2} \mathrm{O}_{2}$ in living cells and monitoring the concentration change of $\mathrm{H}_{2} \mathrm{O}_{2}$ in the human body are going to become a pivotal focus for biology. As an important tool, fluorescent probes have become a research hotspot in life sciences because it can greatly reduce the detection limit and has strong sensitivity and selectivity. As Scheme 1 shows, the binding of $\mathrm{H}_{2} \mathrm{O}_{2}$ to response group can lead to either enhancement (turn-on), quenching (turn-off) or ratio change of the fluorescence intensity, coupled with a red or blue shift of the emission band or absorption band. Here selective fluorescent probes are used for monitoring $\mathrm{H}_{2} \mathrm{O}_{2}$. In order to gain a better analysis on how $\mathrm{H}_{2} \mathrm{O}_{2}$ is generated in living systems as well as to illustrate its biological roles.

In 1965, Richard Brandt and Albert Keston designed a stable reagent probe 1 (Fig. 2) to detect $\mathrm{H}_{2} \mathrm{O}_{2}$, inspired by Schales. ${ }^{31,32}$ In the presence of $\mathrm{H}_{2} \mathrm{O}_{2}$, nonfluorescent compound 1 can rapidly oxidized to a fluorescent compound. Shortly after publication of this paper, Stephen Hempel and Duane Wessels used probe 1 as a detector of intracellular oxidants. ${ }^{33}$ Their work demonstrated that probe $\mathbf{1}$ was a better fluorescent probe for detecting intracellular oxidants such as hydroxyl radical and

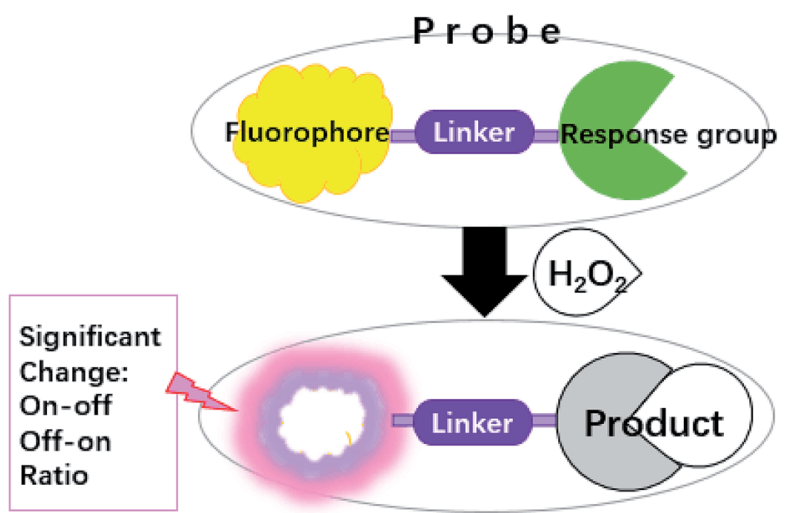

Scheme 1 Design of the fluorescence molecular probes for $\mathrm{H}_{2} \mathrm{O}_{2}$ detection.

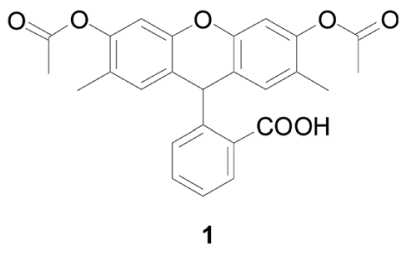

Fig. 2 Structure of probe 1

nitric oxide because it is more reactive toward specific oxidizing species.

With the development of technology, fluorescence analysis is becoming maturer and maturer. Thus, the number of fluorescent probes for detecting $\mathrm{H}_{2} \mathrm{O}_{2}$ is increasing gradually. The application of fluorescent probe to expound biological events relate to $\mathrm{H}_{2} \mathrm{O}_{2}$ has significantly promote the progress of $\mathrm{H}_{2} \mathrm{O}_{2}$ probes in the field of medicine and biology. In this review, five types of $\mathrm{H}_{2} \mathrm{O}_{2}$-specific fluorescent probes in probes treasury will mainly summarized and introduced based on their response group, including arylboronate-based probes, sulfonate-based probes, benzoyl-based probes, $o$-benzenediol based probes and enamine-based probes. These probes can not only largely improve selectivity and sensitivity to $\mathrm{H}_{2} \mathrm{O}_{2}$, but are also widely used as agents for bioimaging of $\mathrm{H}_{2} \mathrm{O}_{2}$. In addition, this review will discuss the molecular mechanism, current situation and prospects of $\mathrm{H}_{2} \mathrm{O}_{2}$ fluorescent probes.

\section{Arylboronate-based fluorescent $\mathrm{H}_{2} \mathrm{O}_{2}$ probes}

Conventional $\mathrm{H}_{2} \mathrm{O}_{2}$ fluorescent probes often comprise a $\mathrm{H}_{2} \mathrm{O}_{2}$ sensing moiety, a fluorophore and a linker. The most commonly used response moiety for $\mathrm{H}_{2} \mathrm{O}_{2}$ is arylboronate, which has developed in many fluorophores to monitor $\mathrm{H}_{2} \mathrm{O}_{2}$ in living cells and tissues. As early as 1957, Henry and Albert ${ }^{34}$ studied the response mechanism of hydrogen peroxide to arylboronic acids in aqueous solutions (Fig. 3). The nucleophilic $\mathrm{H}_{2} \mathrm{O}_{2}$ attacks the electrophilic aryl borate to form an unstable intermediate, which was hydrolyzed to produce phenol and boric acid quantitatively.

In 2003, Lo and co-workers ${ }^{35}$ first developed probe $\mathbf{2 a}$ and $\mathbf{2 b}$ (Fig. 4), whose skeleton consisted of the same response site and

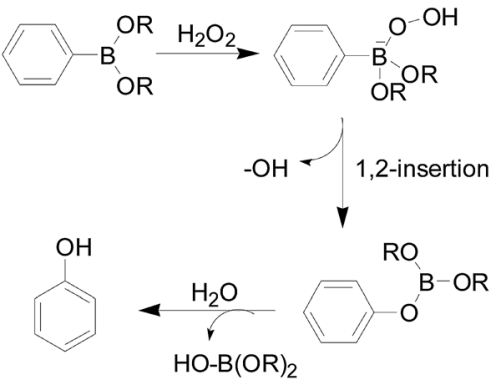

Fig. 3 Mechanism of fluorescent probes based on arylboronate functionality to $\mathrm{H}_{2} \mathrm{O}_{2}$. 


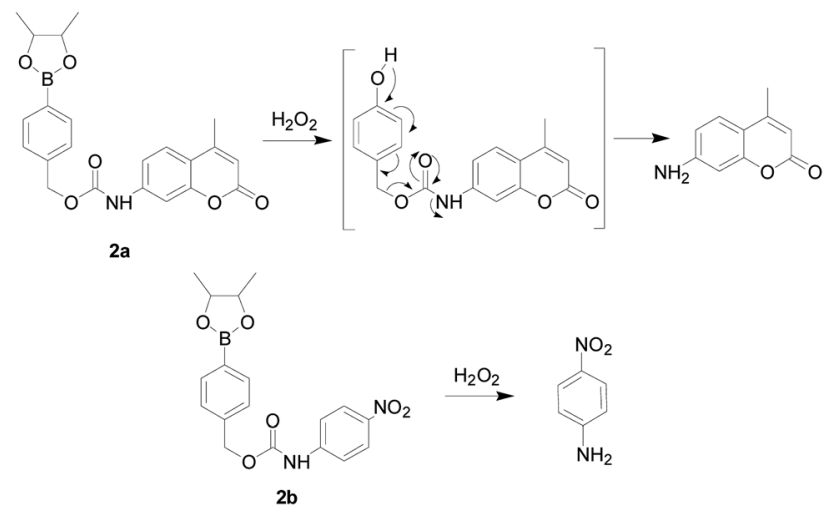

Fig. 4 Sensing mechanism of probe $2 \mathrm{a}$ and $2 \mathrm{~b}$ by $\mathrm{H}_{2} \mathrm{O}_{2}$.

the different amino group as suitable reporter groups. Both of these stable probes could be activated upon reaction with $\mathrm{H}_{2} \mathrm{O}_{2}$ and released the corresponding sensing group. A good linear reaction between the released $p$-nitroaniline or coumarin group and the hydrogen peroxide in the solution. The difference was that probe $2 \mathrm{a}$ provided a more sensitive detection range ( 0.1 to 5 $\mathrm{mM}$ ) than probe $\mathbf{2 b}$. Carried different special properties reporter groups could not affect the detecting mechanism was the major advantages in the design of the probes in this article, which could be used to meet the demands. However, the response time of both probes was much longer. Therefore, these probes have not been used in cell imaging experiments.

In 2004, Chang's group ${ }^{36}$ reported a $\mathrm{H}_{2} \mathrm{O}_{2}$ probe 3 (Fig. 5), they first introduced a pinacol borate into a fluorescent probe. It was a new water-soluble, turn-on optical probe, containing two boronic ester groups at the $3^{\prime}$ and $6^{\prime}$ positions of a xanthenone scaffold as a response moiety. It is worth mentioning that probe 3 had a high selectivity and sensitivity, exhibiting a $>500$-fold higher response for $\mathrm{H}_{2} \mathrm{O}_{2}$ over other similar ROS such as $\cdot \mathrm{OH}$ or
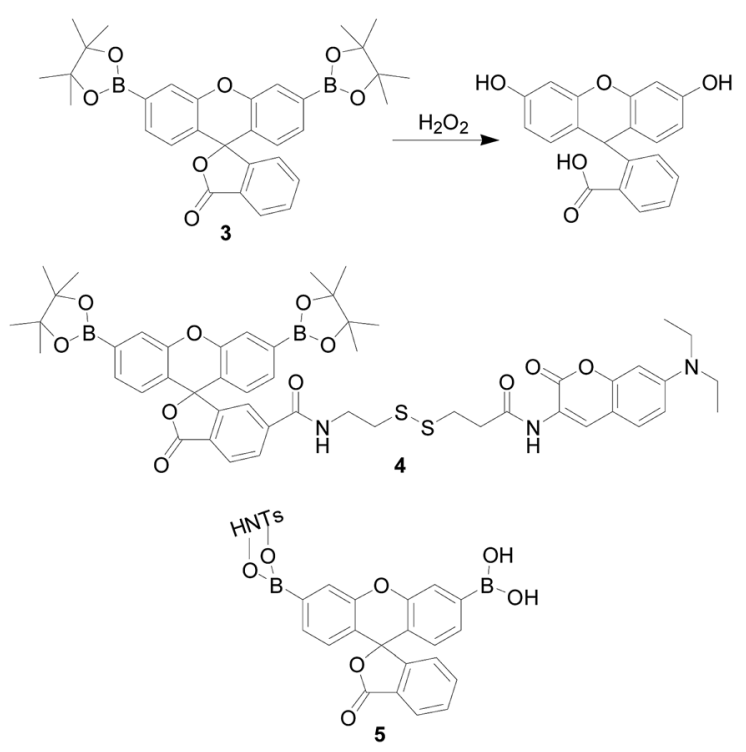

Fig. 5 Fluorescence response of 3 to $\mathrm{H}_{2} \mathrm{O}_{2}$ and the structure of 4 and 5 .
$\mathrm{OCl}^{-}$. The authors believe this is because the reaction is a deprotection process rather than an oxidation reaction. Furthermore, the probe was applied to fluorescence imaging of exogenous $\mathrm{H}_{2} \mathrm{O}_{2}$ in human embryonic kidney cells (HEK293T cells) and good results were obtained. Subsequently, this research group ${ }^{37-40}$ designed a series of probes based on this mechanism. The commonality of these probes were fluorescein used as a fluorophore, an aryl boronate used as a response site, and structural modification performed there on. In the same year, Zhao and colleagues ${ }^{41}$ designed a dual-response fluorescent-opening probe 4 (Fig. 5), which connected the PF1-derivative to the coumarin unit via a disulfide bond, and simultaneously responds to $\mathrm{H}_{2} \mathrm{O}_{2}$ and bio-thiols. The team evaluated the selectivity and sensitivity of the probe and found that probe 4 showed a positive response to $\mathrm{H}_{2} \mathrm{O}_{2}$ and thiolcontaining DL-dithiothreitol (DTT), glutathione (GSH), homocysteine (Hcy), and cysteine (Cys) only. Furthermore, $\mathrm{H}_{2} \mathrm{O}_{2}$ exhibited a different response than DTT, GSH, Hcy and Cys. When the probe was treated with $\mathrm{H}_{2} \mathrm{O}_{2}$, the di-borate group converted to a hydroxyl to form a highly fluorescent fluorescein derivative, and the original PET process converted to an intramolecular FRET mechanism to cause the fluorescence to turn on. Probe 4 could be activated by endogenous thiol and exogenous $\mathrm{H}_{2} \mathrm{O}_{2}$, and thus had the applicability to both inside and outside the cell. However, the response time and detection limit were not satisfactory. In 2017 , Hailei Zhang's team ${ }^{42}$ modified the nanoparticle HNTs with fluorescein derivative PA to prepare probe 5 (PA-HNTs), which has a highly specific fluorescent "turn-on" response to $\mathrm{H}_{2} \mathrm{O}_{2}$. Nanocomposites exhibit regular morphology and good dispersibility in aqueous solution (Fig. 5). Experiments showed that 5 can monitor $\mathrm{H}_{2} \mathrm{O}_{2}$ produced by A549 cells under physiological conditions, which provided a good tool for tumor diagnosis. In order to track $\mathrm{H}_{2} \mathrm{O}_{2}$ at a low level to prevent and diagnose related diseases, it was necessary to develop a $\mathrm{H}_{2} \mathrm{O}_{2}$ sensitive fluorescent probe.

The group headed by Binghe Wang ${ }^{43}$ reported a simple fluorescent probe that directly binds the borate ester group to coumarin. This probe showed 100-fold increase in fluorescent intensity upon reaction with $\mathrm{H}_{2} \mathrm{O}_{2}$ and showed selectivity over other ROS, but the probe had a short emission wavelength at $454 \mathrm{~nm}$. Subsequently, the research group ${ }^{44}$ improved this conjugate system by introducing a triazole into the molecule to obtain a new probe 6 (Fig. 6). Its emission wavelength was red shifted to $474 \mathrm{~nm}$, and its selectivity to $\mathrm{H}_{2} \mathrm{O}_{2}$ was 2-4 times higher than that of other ROS, which was more suitable for cell and in vivo imaging. But the disadvantage was that the fluorescent intensity only increased 5 -fold. In the above reports, borate ester group could be used as the response site of

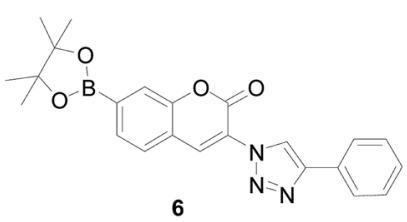

Fig. 6 Structure of fluorescent probe 6 . 
hydrogen peroxide, and both have good selectivity. However, the sensitivity were not high, and the absolute fluorescence intensity was low, which affected the test in cells imaging. In recent years, more and more fluorophore was used as the framework of the probe.

In 2014, Shijun Shao's group ${ }^{45}$ reported a case of BODIPY derivatives 7 (Fig. 7), which were synthesized by introducing 4(bromomethyl)benzeneboronic acid pinacol eater moiety, and showed good solubility in water and "turn-on" fluorescent probe for the discrimination of $\mathrm{H}_{2} \mathrm{O}_{2}$. Probe 7 expresses excellent response toward $\mathrm{H}_{2} \mathrm{O}_{2}$ among the various ROS or RNS and biologically relevant species. Before binding with $\mathrm{H}_{2} \mathrm{O}_{2}$ the probe hardly had fluorescence due to the photo-induced electron transfer (PET) progress. Incubation of probe with $\mathrm{H}_{2} \mathrm{O}_{2}$ would release fluorophore, and the fluorescence of BODIPY was restored. Furthermore, the probe was successfully applied for both in vitro and in vivo imaging of $\mathrm{H}_{2} \mathrm{O}_{2}$ using cells and angelfish. In 2016, this research group ${ }^{46}$ designed and synthesized another $\mathrm{H}_{2} \mathrm{O}_{2}$ fluorescence probe 8 (Fig. 7), which also based on borate ester hydrolysis mechanism. Similar to the luminescence mechanism of probe 7 , before binding with $\mathrm{H}_{2} \mathrm{O}_{2}$ probe 8 showed no fluorescence due to the PET effect, and the PET effect disappeared after the reaction with $\mathrm{H}_{2} \mathrm{O}_{2}$, the fluorescence of carbazole group was recovered. Moreover, probe 8 has excellent selectivity and only $\mathrm{H}_{2} \mathrm{O}_{2}$ shows significant fluorescence enhancement. Other ROS or RNS, such as $\mathrm{HOCl}, \mathrm{O}_{2}{ }^{-}$, $\cdot \mathrm{OH}, \mathrm{NO}, \mathrm{ONOO}^{-}$, and $\mathrm{GSH}$, ascorbic acid, glucose do not initiate or cause only minor changes. The probe has been successfully applied for monitoring and imaging of endogenous $\mathrm{H}_{2} \mathrm{O}_{2}$ in HeLa cells under physiological conditions. In addition, the structural modification of the carbazole pyridinium core provides a unique fluorescent material that opens the way for the construction of new fluorescent materials with unique optical properties.

Based on the PET mechanism, Weiying Lin's group ${ }^{47}$ synthesized a fluorescent "turn-off" probe 9 (Fig. 8), which introduced carbazole-based fluorophore as a fluorescent dye and have PET process after reaction with $\mathrm{H}_{2} \mathrm{O}_{2}$. But unlike the above PET probe, there was no PET effect in the molecule before

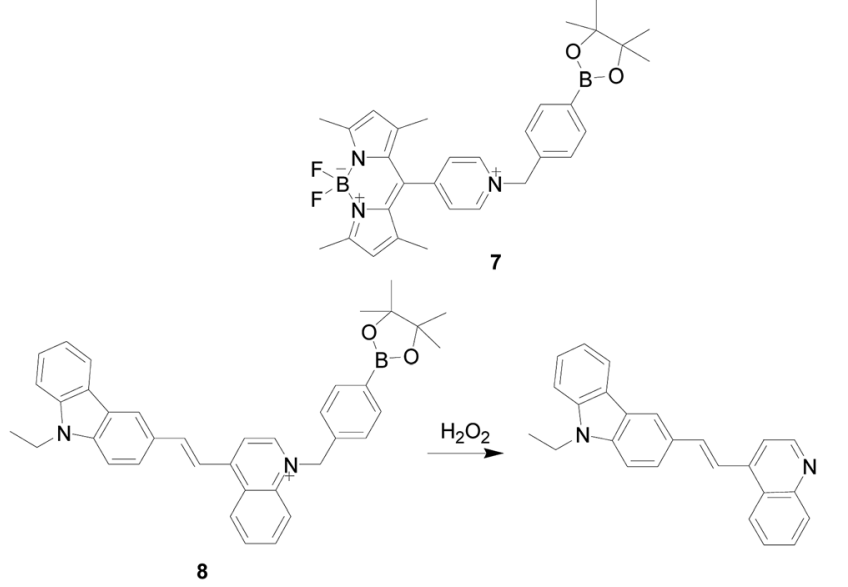

Fig. 7 Structure of probe 7 and the mechanism of probe 8 with $\mathrm{H}_{2} \mathrm{O}_{2}$.
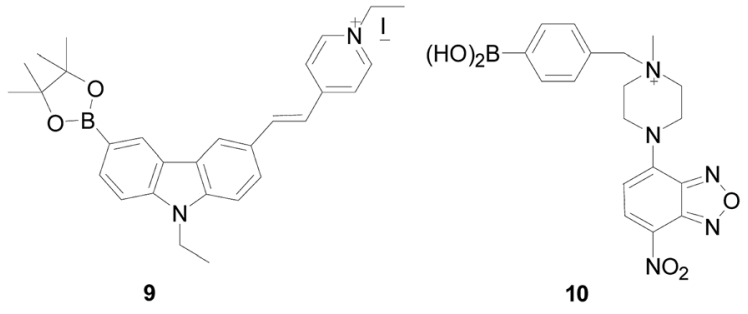

Fig. 8 Structures of probes 9 and 10 .

combined with $\mathrm{H}_{2} \mathrm{O}_{2}$. Probe 9 displayed strong green fluorescence before reaction with $\mathrm{H}_{2} \mathrm{O}_{2}$ but showed low fluorescence after reaction with $\mathrm{H}_{2} \mathrm{O}_{2}$. The probe has a large Stokes shift (157 $\mathrm{nm}$ in water) in various solutions, which can maintain the accuracy of bioimaging, minimize the self-quenching effect, and achieve highly sensitive detection of $\mathrm{H}_{2} \mathrm{O}_{2}$ in aqueous solution. The next year, Xiaowei Xu's group ${ }^{48}$ designed probes 10 (Fig. 8), in that they introduced 4-chloro-7-nitro-1,2,3benzoxadiazole as the fluorophore core, and aryl boronate as a specific $\mathrm{H}_{2} \mathrm{O}_{2}$-reactive group. Upon exposure to $\mathrm{H}_{2} \mathrm{O}_{2}$ probe 10 exhibited distinct "turn-off" behaviors, and could be used in both neutral and alkaline aqueous conditions.

Although many probes for detection of $\mathrm{H}_{2} \mathrm{O}_{2}$ have been explored, rapid response probes are still expected. Based on intramolecular charge transfer (ICT), Wang and co-workers ${ }^{49}$ synthesized fluorescent probe 11 (Fig. 9), which applied phenanthroimidazol, benzonitrile, and phenyl boronate as the three-component. Through introduction of benzonitrile as an electron-withdrawing group formation of a push-pull molecular mechanism modulation ICT process of probe 11, it can be detected $\mathrm{H}_{2} \mathrm{O}_{2}$ with good sensitivity not only in vitro but also in vivo. Moreover, compared to $\mathrm{H}_{2} \mathrm{O}_{2}$, probe $\mathbf{1 1}$ has high selectivity and negligible interference with other substances, including peroxyacetic acid $\left(\mathrm{CH}_{3} \mathrm{COOOH}\right), \cdot \mathrm{OH}, \mathrm{O}_{2}{ }^{-}$and $\mathrm{HOCl}$. The probe 11 can image $\mathrm{H}_{2} \mathrm{O}_{2}$ in the peritoneal cavity of mice. However, the emission is at blue, so it was not perfect to used in vivo.

There is increasing evidence indicating that lysosomes are important site for $\mathrm{H}_{2} \mathrm{O}_{2}$ production under both physiological and pathological conditions. Therefore, to design and synthesis of targeted $\mathrm{H}_{2} \mathrm{O}_{2}$ probe molecules is more important for the application of probes in organisms. In 2016 and 2017, Yibing Zhao's group ${ }^{50,51}$ designed two lysosomal-targeted $\mathrm{H}_{2} \mathrm{O}_{2}$ probes 12 and 13 (Fig. 10). Probe 12 is a pH-switchable fluorescent $\mathrm{H}_{2} \mathrm{O}_{2}$-probe that responds sequentially to intracellular $\mathrm{H}_{2} \mathrm{O}_{2}$

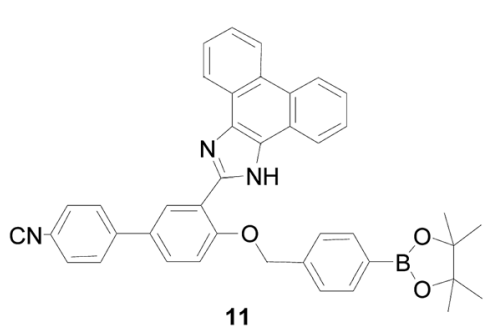

Fig. 9 Structure of probe 11. 


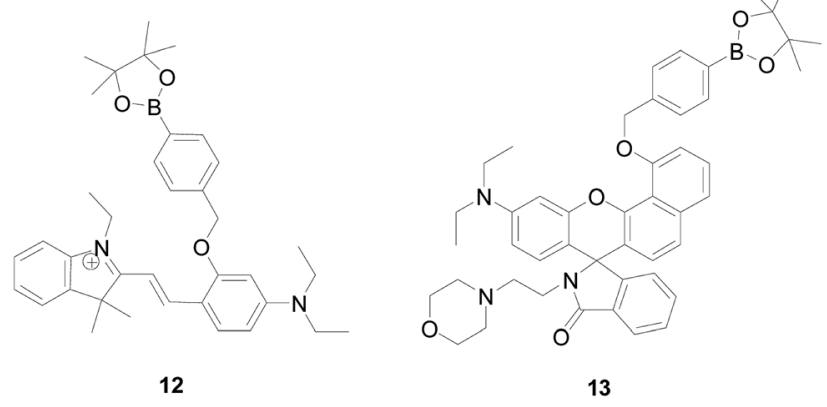

Fig. 10 Structures of probes 12 and 13

and lysosomal $\mathrm{pH}$, enabling the detection of the overall level of intracellular $\mathrm{H}_{2} \mathrm{O}_{2}$ by detecting the fluorescent signal intensity of lysosomes. This was because that probe $\mathbf{1 2}$ possesses a spirobenzopyran fluorophore emitting strongly at lower $\mathrm{pH}$, showing high specificity to $\mathrm{H}_{2} \mathrm{O}_{2}$ and used for live cell imaging. The sensing strategy enables the visualization of the intracellular $\mathrm{H}_{2} \mathrm{O}_{2}$ through the lysosome windows more specifically, providing a new strategy for the spatially confined imaging in certain cell regions. Whereas, probe $\mathbf{1 3}$ is a novel acid activating probe with the same benzorhodol fluorophore as the probe described above. Probe 13 exhibits higher fluorescence intensity and longer emission wavelengths to $\mathrm{H}_{2} \mathrm{O}_{2}$, showing that $\mathbf{1 3}$ is more suitable for the monitoring of $\mathrm{H}_{2} \mathrm{O}_{2}$ under acidic conditions compared to Lyso-B-L2 and Lyso-B-L3. The fluorescence response of probe $\mathbf{1 3}$ to $\mathrm{H}_{2} \mathrm{O}_{2}$ and $\mathrm{H}^{+}$is highly selective, while the presence of other ROS, small bio-thiols, and metal ions does not cause a change in fluorescence. It is worth noticing that probe $\mathbf{1 3}$ uses morpholine as a localization group to provide $\mathrm{p} K_{\mathrm{a}}$ suitable for lysosomal environment and efficient lysosomal localization ability. The probe is capable of fluorescently sensing endogenous lysosomal $\mathrm{H}_{2} \mathrm{O}_{2}$ in living cells, without signal interference from cytoplasm and other intracellular organelles.

The probe 14 (Fig. 11) was designed by Bo Tang's group, ${ }^{52}$ which is a powerful tool for monitoring $\mathrm{H}_{2} \mathrm{O}_{2}$. The probe based on the aggregation induced luminescence (AIE) mechanism. When $\mathrm{H}_{2} \mathrm{O}_{2}$ was present in the system, the benzoborate groups in the probe were transformed into phenol groups, which increased the tetraphenylethylene aggregation. Upon reaction with $\mathrm{H}_{2} \mathrm{O}_{2}$, the fluorescence intensity of the probe $\mathbf{1 4}$ increased at $500 \mathrm{~nm}$ and reached a maximum value within 10 minutes. Probe 14 displayed a high selectivity toward $\mathrm{H}_{2} \mathrm{O}_{2}$ and a linear relationship with the concentration of $(10-200 \mu \mathrm{M})$, and the detection limit was as low as $0.52 \mu \mathrm{M}$. Based on the above advantages, probe $\mathbf{1 4}$ has successfully applied to the imaging of RAW264.7 cells in mice. One of the most significant advantages of AIE-active probes is that they can applied to different conditions. For example, they can workable in solutions, aggregated and even solid states. Based on this, Benzhong Tang's research group ${ }^{53}$ synthesized probe 15 (Fig. 11), which introduces phenylboronic pinacol ester on the AIE fluorogens (AIEgens). The same as probe 14, when combined with $\mathrm{H}_{2} \mathrm{O}_{2}$ the probe's benzoborate groups were transformed into phenol. At

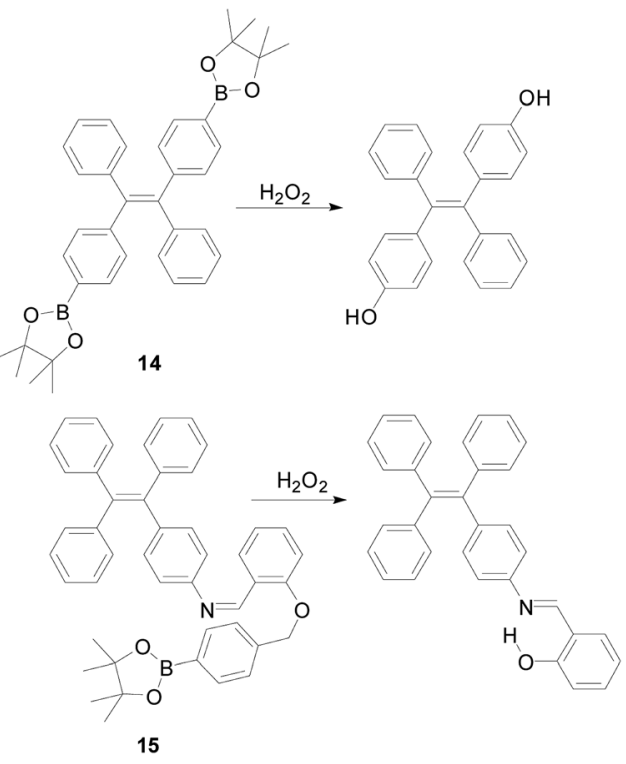

Fig. 11 Reaction of probes 14 and 15 with $\mathrm{H}_{2} \mathrm{O}_{2}$.

the same time, the probe forms a product with bright yellow fluorescence and the hydrogen bond in the product interact to detect of hydrogen peroxide with high sensitivity and high selectivity. The probe can also detect the concentration of glucose. The detection limit of probe $\mathbf{1 5}$ is as low as $100 \mathrm{~nm}$, which is more sensitive than probe $\mathbf{1 4}$.

Yang and colleagues ${ }^{54}$ loaded a triarylboron-based AIE fluorophore on poly-urethane nanogel achieved probe 16 (Fig. 12). The boronate group can functionalize the triarylboron compound and give it the property of a fluorescence probe, which can provide continuous responses to $\mathrm{H}_{2} \mathrm{O}_{2}$. In addition, the introduced boronate group can also endow the triarylboron compound with AIE properties based on the dark TICT mechanism. By incorporating 16 into a polyurethane nanogel, they successfully utilized its photophysical properties to achieve a ratio readout for $\mathrm{H}_{2} \mathrm{O}_{2}$, and cells imaging can experience a color change from yellow green to blue green, which makes it suitable for potential applications in biology and medicine.

Hydrolysis of benzoborate ester groups was also used, Weiying Lin's research group ${ }^{55}$ designed probe 17 (Fig. 12). In this probe, the double bond and benzene were used as a connector to connect the electron donor ( $N, N$-dimethylamino) and electron acceptor (pyridinium cations), which can make the

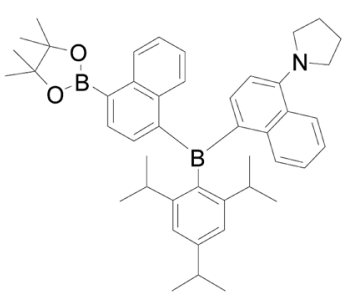

16

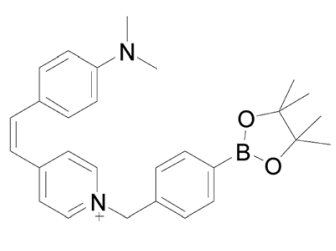

17
Fig. 12 Structures of probes 16 and 17. 
molecular free rotation in the excited state. Because the ability of pyridinium cations has a significant change in the probe $\mathbf{1 7}$ before and after reacting with $\mathrm{H}_{2} \mathrm{O}_{2}$, the excited state of the reaction product could not form the twisted internal charge transfer (TICT) state, the product have a strong fluorescence emission. The probe's emission intensity and the concentration of $\mathrm{H}_{2} \mathrm{O}_{2}$ in range of $0-30 \mu \mathrm{M}$ shows a linear relationship. The probe 17 showed a highly sensitivity and the detection limit was $2.1 \times 10^{-6} \mathrm{M}$ which is sensitive enough to determine the $\mathrm{H}_{2} \mathrm{O}_{2}$ level of the lesion. Moreover, probe $\mathbf{1 7}$ is more selective for $\mathrm{H}_{2} \mathrm{O}_{2}$ than other reference species such as ROS/RNS. In addition, pyridinium cation, as one of the mitochondrial targeting groups, possesses superior membrane permeability and can rapidly enter the mitochondria in cells in a short time. The discovery of this probe laid the foundation for future research on Alzheimer's disease. Based on similar mechanism, Xueping Feng's group ${ }^{56}$ synthesized a probe HPQB, which also can detect $\mathrm{H}_{2} \mathrm{O}_{2}$ and glucose in cells.

In 2018, Zhou Bo's group ${ }^{57}$ reported a probe 18 (Fig. 13), which introduced another mitochondrial targeting group alkylated triphenylphosphine in it. Probe 18 is specific for $\mathrm{H}_{2} \mathrm{O}_{2}$, with only $\mathrm{H}_{2} \mathrm{O}_{2}$ inducing significant fluorescence enhancement, while other ROS and RNS triggering no or limited changes. In addition, probe 18 demonstrated excellent water solubility and applied under physiological $\mathrm{pH}$ condition along with low cytotoxicity, and tracked of mitochondrial $\mathrm{H}_{2} \mathrm{O}_{2}$ in living cells. Therefore, the probe was expected to use as a tool to explore the biological effects of mitochondrial $\mathrm{H}_{2} \mathrm{O}_{2}$, and to facilitate the study of mitochondrial-targeted anticancer drugs. As early as 2008, the probe 19 (Fig. 13) was designed and synthesized by Chang's research group, ${ }^{39}$ which introduced triphenylphosphine as a mitochondrial targeting group. Probe 19 could selectivity detect $\mathrm{H}_{2} \mathrm{O}_{2}$ in the mitochondria of living cells over other ROS like $\cdot \mathrm{OH}, \mathrm{O}_{2}{ }^{-}$, NO. Moreover, the level of $\mathrm{H}_{2} \mathrm{O}_{2}$ in mitochondria of various mammals and the increase of $\mathrm{H}_{2} \mathrm{O}_{2}$ caused by oxidative stress in Parkinson's disease model can be observed through imaging changes.

In order to reduce background interference and cell damage, enhance optical transparency of tissue and the ability to interrogate thicker specimens, it is increasingly important to design and synthesize probes that can emit spectra in the visible farred to near infrared-region. Chang's group ${ }^{\mathbf{4 0}}$ synthesized probe 20 (Fig. 14), which is a new borate-based red-emitting fluorescent indicator for $\mathrm{H}_{2} \mathrm{O}_{2}$. The probe was capable of responding to changes in exogenous $\mathrm{H}_{2} \mathrm{O}_{2}$ levels within RAW264.7 cells. However, as the absolute fluorescent brightness of
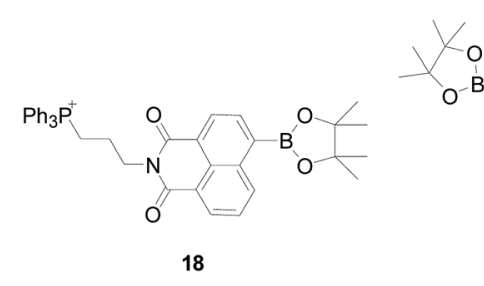

Fig. 13 Structures of probes 18 and 19

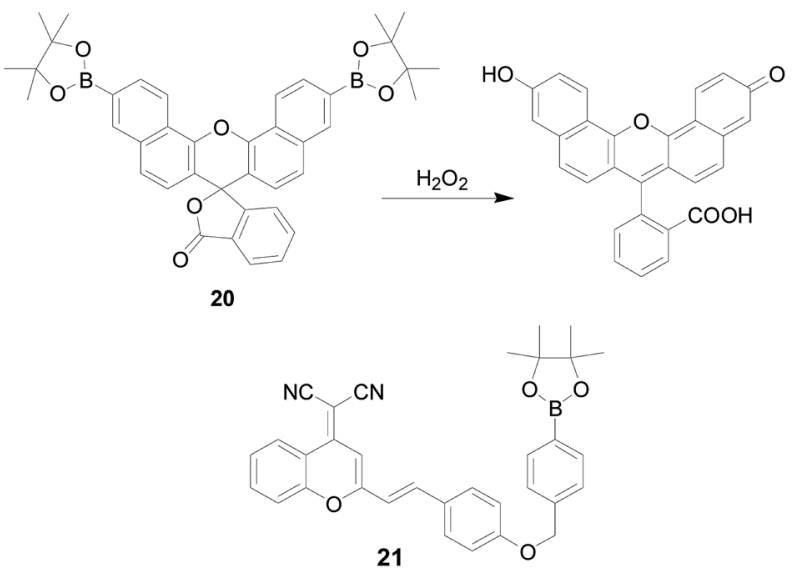

Fig. 14 Reaction of probe 20 with $\mathrm{H}_{2} \mathrm{O}_{2}$ and the structure of 21 .

naphthofluorescein was weaker than fluorescein and other fluorophore used previously, attempts to use this probe to study oxidative stress in cells have failed. Haitao Li's team ${ }^{58}$ designed a new near-infrared probe 21 (Fig. 14) with dicyanomethylene$4 H$-pyran moiety as fluorophore and borate ester as the recognition unit. The probe was "turn-off" response based on the ICT mechanism. After probe 21 was cultivated with $\mathrm{H}_{2} \mathrm{O}_{2}$, the recovery of the ICT process resulted in an obvious increase in fluorescence emission at $688 \mathrm{~nm}$, accompanied by a distinct color change from yellow to purple, revealing the feasibility of "naked-eye" monitoring $\mathrm{H}_{2} \mathrm{O}_{2}$. Encouraged by the properties of near-infrared emission, probe $\mathbf{2 1}$ was successfully applied in the imaging of exogenous and endogenous $\mathrm{H}_{2} \mathrm{O}_{2}$ in HepG2 cells.

Liyi Zhou's group ${ }^{59}$ constructed a two-photon near-infrared fluorescent probe 22 (Fig. 15), which introduced the oxonium ion as the mitochondrial targeting unit and phenylboric acid as the $\mathrm{H}_{2} \mathrm{O}_{2}$ reaction moiety. Probe 22 could successfully applied for $\mathrm{H}_{2} \mathrm{O}_{2}$ imaging of liver tissue up to $170 \mu \mathrm{m}$ depth in red fluorescence channels. After reacting with $\mathrm{H}_{2} \mathrm{O}_{2}$, the fluorescence intensity of probe 22 increased significantly by more than 105 times at the emission wavelength of $665 \mathrm{~nm}$, which is much larger than other ROS, which meets the selectivity requirements of practical applications. Furthermore, the probe has good dyeing ability and high penetrating ability to $\mathrm{H}_{2} \mathrm{O}_{2}$ image tissue, and can be applied to liver tissue $\mathrm{H}_{2} \mathrm{O}_{2}$ images with a depth of 50-170 $\mu \mathrm{m}$ in a red fluorescent channel.

More and more borate fluorescent probes were used to detect hydrogen peroxide in cells. However, most of these probes were single-photon imaging technology. In addition to the 
description above, there were many probes designed using this technique. ${ }^{60-70}$ The photo-damage and photo-bleaching properties of single photon imaging technology have prevented longterm imaging during bioimaging process, and it has strong background interference and low UV transmittance, which limits their applications in deep tissue imaging. By contrast, two-photon (TP) fluorescent probes can greatly overcome these defects. By using near-infrared (NIR) lights as the excitation source, the two-photon fluorescent probes can reduce the photo-damage and photo-bleaching caused by single-photon fluorescent probes, increase tissue penetration, and promote three-dimensional imaging of living tissue. Hence, the twophoton probes are more suitable for biological detection and imaging, providing sharper tool for life science research.

Probe 23 (ref. 71) (Fig. 16) was the first developed and reported two-photon fluorescent probe for $\mathrm{H}_{2} \mathrm{O}_{2}$, which introduced a boronate-based carbamate leaving group to 2-acetyl-6aminonaphthalene (AN1), designed by Bong Rae Cho and coworkers, suitable for deep tissue imaging. After adding $\mathrm{H}_{2} \mathrm{O}_{2}$ to the solution, probe $\mathbf{2 3}$ was converted into AN1. Probe $\mathbf{2 3}$ can be excited by $750 \mathrm{~nm}$ femto-second pulses, showing a significant TP cross section, a marked blue-to-green emission color change in response to $\mathrm{H}_{2} \mathrm{O}_{2}$, good ROS selectivity, and insensitivity to $\mathrm{pH}$ in the biologically. In addition, probe $\mathbf{2 3}$ was capable of visualizing $\mathrm{H}_{2} \mathrm{O}_{2}$ levels in both RAW264.7 cells and tissue models at depths of $90-180 \mathrm{~mm}$ without interference from other biologically relevant species. In order to study the complex relationship between lysosomes and physiological $\mathrm{H}_{2} \mathrm{O}_{2}$, Weiying Lin's team ${ }^{72}$ developed a fast-response and lysosomal targeted two-photon fluorescent probe 24 (Fig. 16), which has a relatively high targeting effect on lysosomes. The probe itself has an " $\mathrm{A}-\pi-\mathrm{A}$ " structure, and after reacting with $\mathrm{H}_{2} \mathrm{O}_{2}$, the borate group becomes a hydroxyl group (electron donating group), and its electronic structure becomes donor- $\pi-$ acceptor "D- $\pi-A$ " structure. This change shows a distinct fluorescence on signal with an 80-fold increase in fluorescence signal, which is attractive for $\mathrm{H}_{2} \mathrm{O}_{2}$ imaging in living tissue with deep tissue penetration. Qiujuan Ma's team ${ }^{73}$ synthesized a highly selected two-photon fluorescent probe 25 (Fig. 16) for $\mathrm{H}_{2} \mathrm{O}_{2}$, based on a naphthalene platform and a boric acid ester $\mathrm{H}_{2} \mathrm{O}_{2}$ response site. Naphthalene backbone with a D- $\pi-\mathrm{A}$ structure, which can improve fluorescence quantum yield and photochemical stability. Probe 25 has good selectivity to $\mathrm{H}_{2} \mathrm{O}_{2}$, and only $\mathrm{H}_{2} \mathrm{O}_{2}$ can cause strong fluorescence intensity

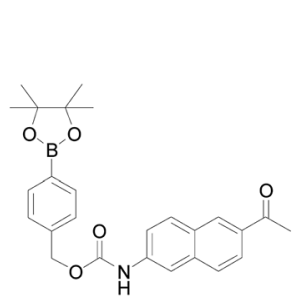

23

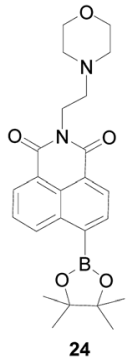

24

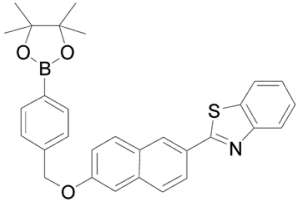

25 enhancement at $505 \mathrm{~nm}$, while other ROS substances will not, including $\mathrm{ONOO}^{-}, \mathrm{O}_{2}^{-}, \mathrm{ClO}^{-}$, $\cdot \mathrm{OH}$, tert-butylhydroperoxide (TBHP), ${ }^{1} \mathrm{O}_{2}$ and NO. It could be applied for quantitative detection of $\mathrm{H}_{2} \mathrm{O}_{2}$ in live cells and tissues with good cellpermeability, and the detection limit was $0.7 \mu \mathrm{M}$. The ointment is that the probe's response time is long and the sensitivity was not wonderful, which requires a further improvement.

Two-photon fluorescence probes for bio-detection and imaging reported in the literature,$^{74}$ the two-photon absorption cross section of most probes was not very satisfactory, and needs further development to improve the sensitivity of detection and the clarity of imaging, and broaden the biological range of imaging. Fluorescence ratiometric eliminates the effects of source intensity and instrument sensitivity. After the probe was combined with $\mathrm{H}_{2} \mathrm{O}_{2}$, the fluorescence intensity ratios measured at two different wavelengths can be calibrated to overcome the artifacts of the fluorescent signal due to changes in ion concentration.

Subsequently, Bong Rae Cho research group ${ }^{75}$ designed and reported probe 26 (Fig. 17), the first two-photon probe for ratiometric detection of $\mathrm{H}_{2} \mathrm{O}_{2}$, which introduced triphenylphosphonium salt as the mitochondria-targeting site, could detected $\mathrm{H}_{2} \mathrm{O}_{2}$ level change in mitochondrial in cellular environments and intact tissues at depth $>100 \mu \mathrm{M}$. After adding $1 \mathrm{mM} \mathrm{H}_{2} \mathrm{O}_{2}$ to a solution of $1 \mu \mathrm{M}$ probe 26 , the ratio $\left(F_{\text {yellow }} /\right.$ $\left.F_{\text {blue }}\right)$ of fluorescence intensity increased by 75 -folds. Hwan Myung Kim's team ${ }^{76}$ used a carboxyl group to replace the triphenylphosphine in probe $\mathbf{2 6}$ and synthesized the probe $\mathbf{2 7}$ (Fig. 17), which also showed a change in fluorescence color from yellow to blue in response to $\mathrm{H}_{2} \mathrm{O}_{2}$. The ratio two-photon microscopy of 27 images displayed that $\mathrm{H}_{2} \mathrm{O}_{2}$ levels gradually increased from brain to kidney, skin, heart, lung, and then liver tissue. In addition, the above two probes exhibited higher selectivity for $\mathrm{H}_{2} \mathrm{O}_{2}$ than competitive biological species, ROS and RNS, and the ratio of $F_{\text {yellow }} / F_{\text {blue }}$ is unperturbed after adding diverse ROS and RNS, including TBHP, $\mathrm{O}_{2}^{-}$, $\mathrm{HOCl}$, NO, $\cdot \mathrm{OH}$, tert-butoxy radicals $(\cdot \mathrm{OtBu})$ and $\mathrm{ONOO}^{-}$. These results indicate that this type of probe will be useful for application in studies of biological and medical research.

Chunhua Fan and colleagues ${ }^{77}$ reported a two-photon $\mathrm{H}_{2} \mathrm{O}_{2}$ specific fluorescent probe 28 (Fig. 18), which based on the ICT mechanism, with 6-hydroxy-2,3,4,4a-tetrahydro- $1 H$-xanthen-1one (TX) as a fluorophore. The probe $\mathbf{2 8}$ has a fast fluorescence response to $\mathrm{H}_{2} \mathrm{O}_{2}$ in 9 minutes, which with high sensitivity, high selectivity and biocompatibility. This probe has been successfully used for imaging $\mathrm{H}_{2} \mathrm{O}_{2}$ in mouse liver tissue. Manoj Kumar and colleagues $^{78}$ also published a charge transfer

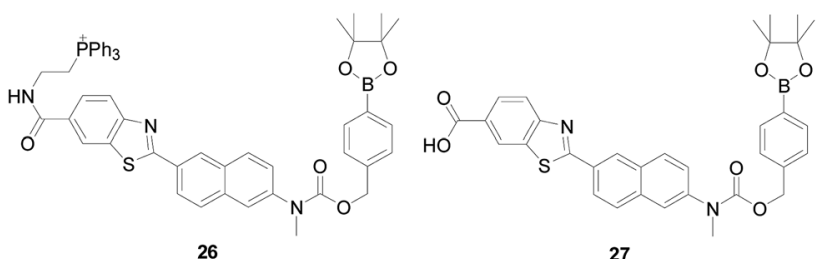

Fig. 17 Structures of fluorescence probes 26 and 27

Fig. 16 Structures of 23, 24 and 25. 


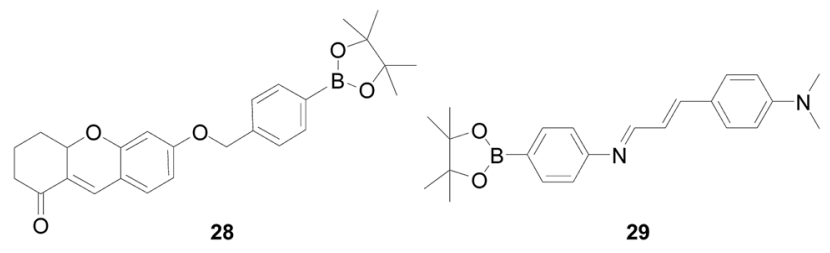

Fig. 18 Structures of fluorescence probes 28 and 29 .

assisted fluorescent probe 29 (Fig. 18), the dimethylamino group is protonated, inhibiting the twisted intramolecular charge transfer from the dimethylamino group to the imine moiety, which causes the emission at $566 \mathrm{~nm}$ to disappear and the higher energy emission occurring at $484 \mathrm{~nm}$. In the case of the $29-\mathrm{H}_{2} \mathrm{O}_{2}$ system, the fluorescence intensity ratio of $I_{484} / I_{566}$ is 9.5-times. It can be said that the probe 29 is $\mathrm{H}_{2} \mathrm{O}_{2}$-specific, and no significant change is observed in other reactive oxygen species. In summary, this probe can detect $\mathrm{H}_{2} \mathrm{O}_{2}$ in prostate cancer (PC3) cell lines in vitro, exploring the potential biological applications of probe.

The fluorescence probe designed with the change of fluorescence intensity at a single wavelength is easily interfered by external factors such as equipment efficiency, environmental conditions and probe concentration, so as to reduce the selectivity and sensitivity of fluorescence probe detection. In contrast, the ratiometric fluorescent probes can overcome these shortcomings by allowing simultaneous detection of two signals resulting from reacted and unreacted forms of the probe in the same sample.

Chang' group ${ }^{79}$ designed a ratiometric fluorescent probe $\mathbf{3 0}$ (Fig. 19), which exhibited a blue fluorescence emission at $475 \mathrm{~nm}$, after the interaction with $\mathrm{H}_{2} \mathrm{O}_{2}$, its emission wavelength was red shifted to $540 \mathrm{~nm}$ by ICT mechanism, resulting in a 12-fold change in the ratio $\left(F_{540} / F_{475}\right)$. Using the ratiometric property of 30, the authors studied the changes of $\mathrm{H}_{2} \mathrm{O}_{2}$ in RAW264.7 cells under stimulated by PMA, found that after probe 30 induction, the fluorescence changes in phagocytic vesicles were more pronounced than in other parts of the cell, which indicated that $\mathrm{H}_{2} \mathrm{O}_{2}$ was produced during phagocytosis.
Shuizhu Wu's research group ${ }^{80}$ developed a nano-fluorescent probe 31 (Fig. 19) based on FRET mechanism, which was stable in spectral properties and easy to modify. Probe $\mathbf{3 1}$ is capable of selectively detecting the fluorescence intensity ratio $\left(I_{550} / I_{457}\right)$ in the presence of $\mathrm{H}_{2} \mathrm{O}_{2}$ and other potentially competitive ROS/ RNS. With the concentration of $\mathrm{H}_{2} \mathrm{O}_{2}$ increases, the fluorescence ratio $\left(I_{550} / I_{457}\right)$ increased steadily. In addition, the coexistence of other species does not affect the detection of $\mathrm{H}_{2} \mathrm{O}_{2}$. As an energy donor and carrier for $\mathrm{H}_{2} \mathrm{O}_{2}$ recognition, carbon dots (CD) have good biocompatibility. ${ }^{81} \mathrm{CD}$-based nanoprobes are small in size and low in toxicity, and can respond quickly to $\mathrm{H}_{2} \mathrm{O}_{2}$, which is beneficial in vivo detection. The probe $\mathbf{3 1}$ is currently capable of monitoring and localizing endogenous $\mathrm{H}_{2} \mathrm{O}_{2}$ in zebrafish caused by oxidative damage to the drug.

Also based on FRET mechanism, Shubao Wu's group ${ }^{82}$ developed a fluorescent probe 32 (Fig. 19), which combined two different fluorophores (coumarin and naphthalimide) forming a two-channel imaging method through dual sensing strategies to detect $\mathrm{H}_{2} \mathrm{~S}$ and $\mathrm{H}_{2} \mathrm{O}_{2}$ in living cells, which can be applied to diagnose cancer. This dual response strategy overcomes the uneven distribution of dual probes, providing accurate information about multiple analytes within the cell, and encourages the development of more fluorescent markers for detecting multiple analytes to label cancer cells.

In recent years, the development of near-infrared and multiphoton quantitative detection of ratiometric probes has become a new trend, with its unique background interference, no biological tissue damage and other unique properties, attracting a wide range of academic attention.

Xiangzhi Song and Wenqiang Chen $^{83}$ combined the ICT and ESIPT mechanisms to design a novel mitochondria-targeted fluorescent probe 33 (Fig. 20) that showed a red fluorescence ratio of $I_{594 \mathrm{~nm}} / I_{666 \mathrm{~nm}}$ at a single excitation wavelength of $440 \mathrm{~nm}$. Unlike other benzothiazole-based ratio probes, probe 33 reacts with $\mathrm{H}_{2} \mathrm{O}_{2}$ to suppress the ICT process, exhibiting a large stoke shift (from $102 \mathrm{~nm}$ to $254 \mathrm{~nm}$ ) and a significant ratio of fluorescence changes. Large Stokes shifts can minimize self-absorption and auto-fluorescence interference. Moreover, it can improve detection sensitivity, and facilitate biological cell
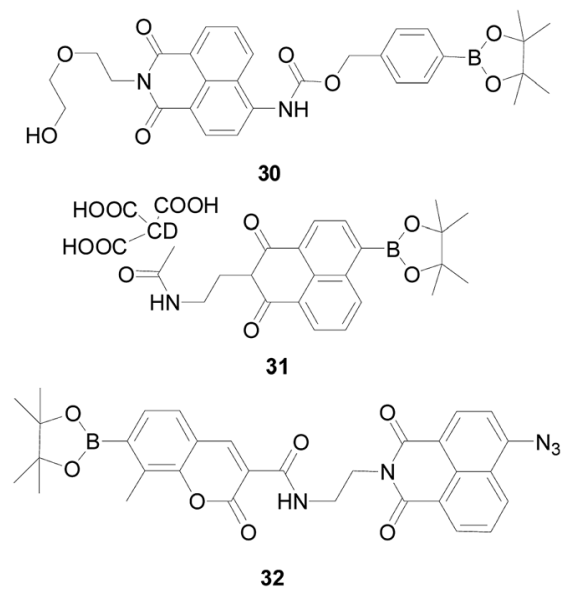

32

Fig. 19 Structures of probes 30, 31 and 32 .

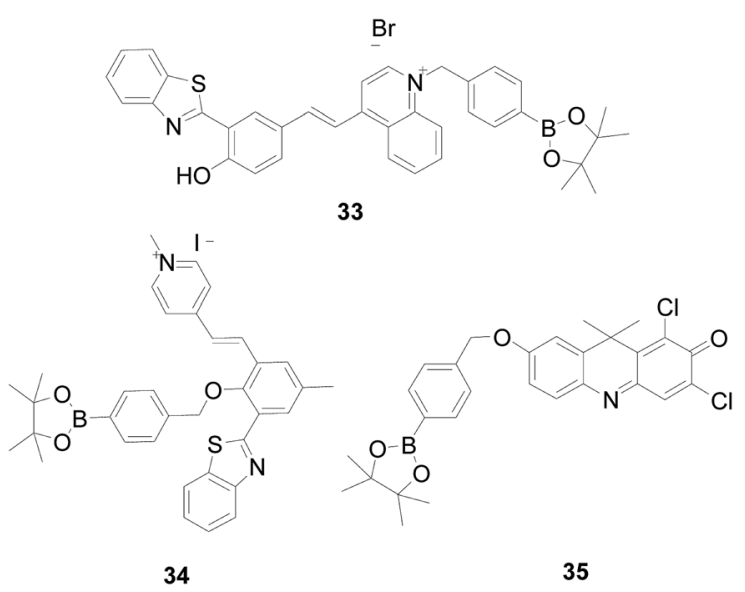

Fig. 20 Structures of probes 33,34 and 35. 
imaging. Lijun Tang's team ${ }^{\mathbf{8 4}}$ also developed a near-infrared mitochondria-targeted ratiometric probe 34 (Fig. 20) with a large stoke shift (357 nm), good sensitivity and selectivity, and has been successfully applied for A549 cell imaging.

By adjusting the intramolecular charge transfer process of dye $\quad 9 H$-1,3-dichloro-7-hydroxy-9,9-dimethylacridine-2-one (DDAO), Yuguang Song's team ${ }^{85}$ synthesized a ratio-type "turnon" near-infrared probe 35 (Fig. 20) with high sensitivity and low background interference. Probe 35 produces a strong orange fluorescence emission at $620 \mathrm{~nm}$, which was converted to DDAO after $\mathrm{H}_{2} \mathrm{O}_{2}$ response, and the wavelength is red shifted to $660 \mathrm{~nm}$ with red fluorescence. Except for $\mathrm{H}_{2} \mathrm{O}_{2}$, no palpable improvement in the fluorescence ratio $\left(F_{660} / F_{620}\right)$ were observed for biological relevant ROS/RNS, GSH, Cys, VC, cations and amino acids. The probe satisfies the need for quantitative monitoring of $\mathrm{H}_{2} \mathrm{O}_{2}$ in the body.

Phenylborate is a classical group that recognizes $\mathrm{H}_{2} \mathrm{O}_{2}$ and has made outstanding contributions to the study of $\mathrm{H}_{2} \mathrm{O}_{2}$. However, the reaction of phenylborate to $\mathrm{H}_{2} \mathrm{O}_{2}$ also has certain disadvantages. Firstly, although a large number of ratiometric probes $^{\mathbf{8 6 - 8 8}}$ have been designed for the quantitative detection of $\mathrm{H}_{2} \mathrm{O}_{2}$, the concentration change of $\mathrm{H}_{2} \mathrm{O}_{2}$ cannot be monitored in real time. In addition, in recent years, there have been reports in the literature ${ }^{89-91}$ that phenylborate can react with $\mathrm{ONOO}^{-}$ and $\mathrm{ClO}^{-}$, and the reaction rate is much faster than that with $\mathrm{H}_{2} \mathrm{O}_{2}$.

Therefore, developing and synthesizing high-selectivity, high-sensitivity, fast responding fluorescent probes for $\mathrm{H}_{2} \mathrm{O}_{2}$ based on new response groups is a significant and challenging task.

\section{Sulfonate-based fluorescent $\mathrm{H}_{2} \mathrm{O}_{2}$ probes}

Similar to the response of the borate to $\mathrm{H}_{2} \mathrm{O}_{2}$, the sulfonate can also be used as a responsive group for $\mathrm{H}_{2} \mathrm{O}_{2}$.

In 2004, Maeda and co-workers ${ }^{92}$ first discovered pentafluorobenzenesulfonyl fluorescein derivatives 36a-c (Fig. 21) as novel selective fluorescent probes for $\mathrm{H}_{2} \mathrm{O}_{2}$ with a sulfonate as a responsive site. The fluorescent precursor of the probe has a high fluorescence quantum yield; the sulfonate is more stable than the general ester and not easily hydrolyzed; the structure of the pentafluorobenzene ring increases the reactivity of the probe with $\mathrm{H}_{2} \mathrm{O}_{2}$. After $\mathrm{H}_{2} \mathrm{O}_{2}$ reacts with the probe 36, the sulfonate was hydrolyzed to release fluorescein, and the

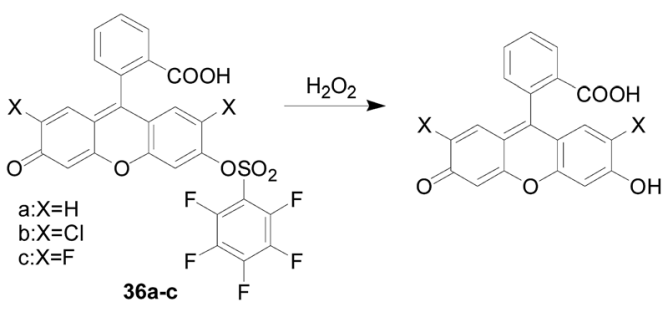

Fig. 21 Reaction of probe $36 \mathrm{a}-\mathrm{c}$ by $\mathrm{H}_{2} \mathrm{O}_{2}$. fluorescence is enhanced. The fluorescence response intensity of this series of probes was also positively correlated with the temperature. As the temperature increased, the detection limit decreased.

Tang Bo's group ${ }^{93}$ presented a disulfonate-responsive probe 37 (Fig. 22) as a fluorescent imaging agent to monitor intracellular $\mathrm{H}_{2} \mathrm{O}_{2}$. Probe 37 is an excellent naphthalene-based fluorescent reagent. Compared with fluorescein, the stent has red-shifted spectral characteristics. After treatment with various concentrations of $\mathrm{H}_{2} \mathrm{O}_{2}$, the probe produces a linear fluorescence response with a low detection limit, good selectivity, reported as a smart probe for $\mathrm{H}_{2} \mathrm{O}_{2}$ in mouse peritoneal macrophages. The same group designed probe $\mathbf{3 8 a}$ and $\mathbf{3 8 b}$ (ref. 94) (Fig. 22), which was based on the mechanism of $\mathrm{H}_{2} \mathrm{O}_{2}$ mediated hydrolysis of sulfonates. The probes introduced two sulfonate groups into the fluorescein chromophore as response sites. Fluorescence experiments showed that probes 38a and 38b had excellent selectivity to $\mathrm{H}_{2} \mathrm{O}_{2}$ over other intracellular ROS and some biological compounds and low detection limit. In addition, the probes based on sulfonate were cell permeable, which can detect the micromole change of $\mathrm{H}_{2} \mathrm{O}_{2}$ concentration and observe living cells with confocal microscope. In consideration of the excellent performance of the probe, the study was conducted to detect both $\mathrm{H}_{2} \mathrm{O}_{2}$ and superoxide in pleural lavage fluid and lung cells. The study was conducted on Wistar rats with bleomycin-induced pulmonary fibrosis. The signal transduction system for determining the content of $\mathrm{H}_{2} \mathrm{O}_{2}$ was developing.

Since the induction of $\mathrm{H}_{2} \mathrm{O}_{2}$ by the fluorescent probe acts based on the different reaction process, the sensitivity of the probe is greatly affected by the reaction rate. It is difficult to improve the reaction rate by changing the chemical structure of the single-molecule probe system. However, as has been reported, ${ }^{93}$ it can be known that real-time imaging of intracellular $\mathrm{H}_{2} \mathrm{O}_{2}$ can be achieved by using a switchable photoluminescent inorganic nanoprobe. Considering the reaction kinetics, Soo Young Park and Sehoon $\mathrm{Kim}^{95}$ devised a simple method to catalyze the sensing reaction by binding a fluorescent probe to a nanoreactor through a catalyst, so that the imaging of $\mathrm{H}_{2} \mathrm{O}_{2}$

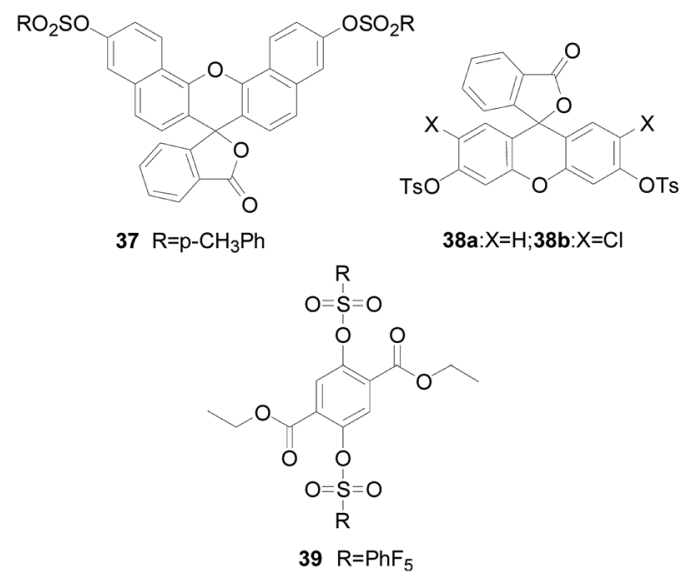

Fig. 22 Structures of probes 37, 38 and 39. 
has improved spatiotemporal resolution during cellular process. The method was proposed entirely based on the hydrolysis of the new probe 39 sulfonate group (Fig. 22), which showed a "turn-off" fluorescence response and real-time imaging of $\mathrm{H}_{2} \mathrm{O}_{2}$.

Recently, Fabiao Yu's team ${ }^{96}$ developed a near-infrared ratio fluorescent probe $\mathbf{4 0}$ (Fig. 23). The probe $\mathbf{4 0}$ itself showed the maximum absorbance centered at $830 \mathrm{~nm}$, with the increase of $\mathrm{H}_{2} \mathrm{O}_{2}$, the fluorescence intensity decreased gradually, and a new absorption peak appeared at $635 \mathrm{~nm}$, which had an excellent linear relationship. The ratiometric signals showed negligible changes for these reactive species including various ROS/RNS ( $\mathrm{HOCl}, \cdot \mathrm{OH},{ }^{1} \mathrm{O}_{2}, \mathrm{O}_{2}{ }^{-}$, $\mathrm{NO}$ and $\mathrm{ONOO}^{-}$) and mercaptan (GSH, Cys, and Glu). The team used the probe $\mathbf{4 0}$ to examine the critical role of endogenous $\mathrm{H}_{2} \mathrm{O}_{2}$ in cell proliferation in viable hippocampal neurons and successfully demonstrated a close association between changes in endogenous $\mathrm{H}_{2} \mathrm{O}_{2}$ levels and brain development at different stages.

\section{Benzoyl-based fluorescent probes for $\mathrm{H}_{2} \mathrm{O}_{2}$}

In 1979, S. Foote team ${ }^{97}$ elaborated the reaction mechanism of benzil with $\mathrm{H}_{2} \mathrm{O}_{2}$, as shown in the Fig. 24. At the beginning, $\mathrm{H}_{2} \mathrm{O}_{2}$ nucleophilic attack on the carbonyl of benzil, then the Baeyer-Villiger reaction occurs to form an unstable intermediate, and the intermediate is rapidly hydrolyzed to produce benzoic acid.

Nagano's group ${ }^{98}$ described a fluorescent "turn-on" $\mathrm{H}_{2} \mathrm{O}_{2}$ probe 41 (Fig. 25) for the first time using benzil as a specific recognition group for $\mathrm{H}_{2} \mathrm{O}_{2}$. They synthesized 5-benzoylcarbonylfluorescein derivatives as candidate fluorescence probes using PET mechanism, finding that when the electronwithdrawing groups $\left(-\mathrm{Br},-\mathrm{CN}\right.$, and $\left.-\mathrm{NO}_{2}\right)$ were attached to the benzil, the reactivity with $\mathrm{H}_{2} \mathrm{O}_{2}$ was significantly enhanced. The stronger the electron absorption of the group, the higher the reactivity of the probe $\mathbf{4 1}$. The results demonstrated that probe $\mathbf{4 1}$ had the highest reactivity, better signal-to-noise ratio with $\mathrm{H}_{2} \mathrm{O}_{2}$, and the highest fluorescence enhancement ratio. Indeed, the enhancement of fluorescence intensity after reaction with hydrogen peroxide was as high as 150-fold. Compared with previously reported fluorescence probes utilizing benzenesulfonyl ester or boronate ester chemistry, the selectivity of probe $\mathbf{4 1}$ among ROS is unique. Which made probe $\mathbf{4 1}$ could be as a useful tool for biological detection. Experiments indicated that the probe could detect endogenous $\mathrm{H}_{2} \mathrm{O}_{2}$ produced by RAW264.7 macrophages and A431 human epidermal cancer

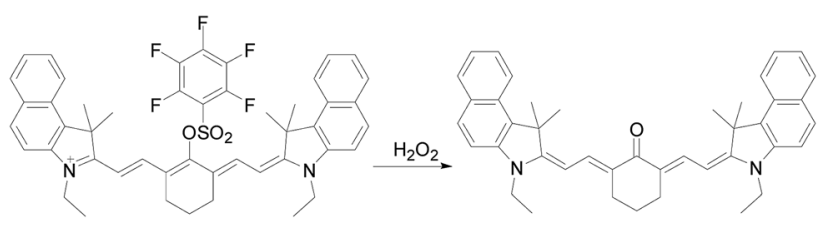

40

Fig. 23 Reaction of probe 40 with $\mathrm{H}_{2} \mathrm{O}_{2}$.

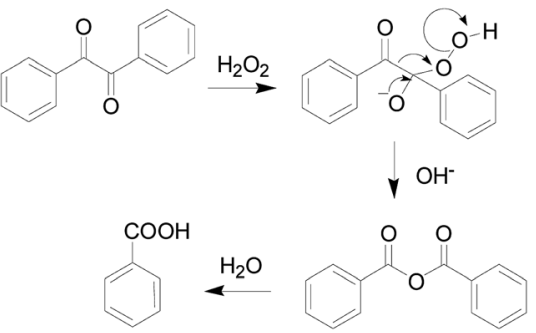

Fig. 24 Reaction mechanism of benzil with $\mathrm{H}_{2} \mathrm{O}_{2}$.

cells. The design strategy used here applied not only to fluorescein derivatives, but also to other fluorophore. In 2014, Hideki Sumimoto research group ${ }^{99}$ also designed and synthesized a fluorescent probe $\mathbf{4 2}$ (Fig. 25) with fluorescein as the nucleus based on the response mechanism of phenyldiethyl ketone, introducing a phage targeted positioning group benzyl guanine. It resulted in the formation of a fluorophore-protein conjugate that reacts rapidly with $\mathrm{H}_{2} \mathrm{O}_{2}$. Probe 42 rapidly reacted with $\mathrm{H}_{2} \mathrm{O}_{2}$ and showed a 9-fold increase in fluorescence intensity. Which successfully applied to monitor endogenous $\mathrm{H}_{2} \mathrm{O}_{2}$ produced during phagocytosis of RAW264.7 macrophages in real time.

Chen Jianbo and colleagues ${ }^{\mathbf{1 0 0}}$ designed new probes 43a and 43b (Fig. 26) using BODIPY as the fluorophore and benzil as the $\mathrm{H}_{2} \mathrm{O}_{2}$ recognition group. Investigating the fluorescent properties of $43 \mathbf{a}$ and $\mathbf{4 3 b}$, finding that $\mathbf{4 3 a}$ and $\mathbf{4 3 b}$ successfully turn on highly green-emitting fluorescence, which satisfies "off-on" fluorescent probes to decrease background interferences. In addition, when they are reacting with excess $\mathrm{H}_{2} \mathrm{O}_{2}$ for 60 minutes, respectively, the fluorescence intensity of $43 \mathbf{a}$ increased by 78 times, much higher than that of $\mathbf{4 3 b}$ (70 times). The authors believe that the above results are because 43a owns a more pronounced steric effect and weaker capacity of the electron withdrawing. Inspired by much better response of 43a to $\mathrm{H}_{2} \mathrm{O}_{2}$, a further step was took to investigate other analytical capabilities of 43a. Since the carboxyl product of 43a reacts with

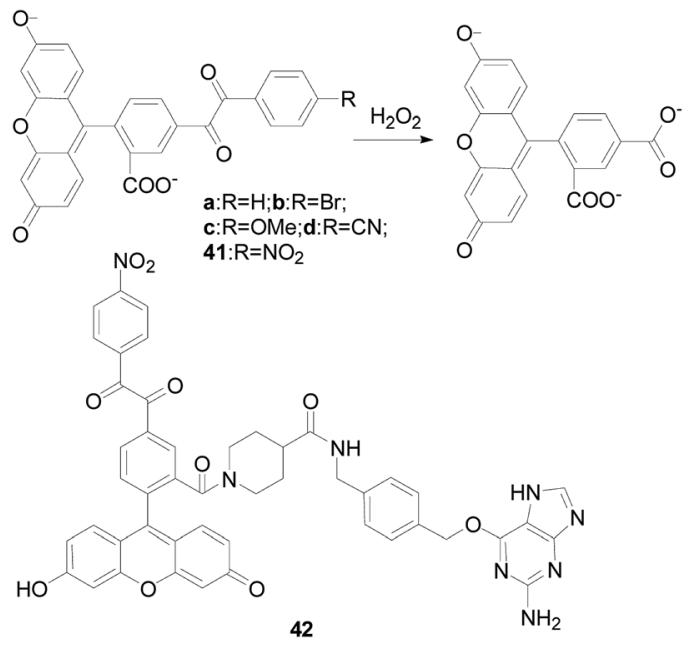

Fig. 25 Reaction of probe 41 with $\mathrm{H}_{2} \mathrm{O}_{2}$ and the structure of 42 . 


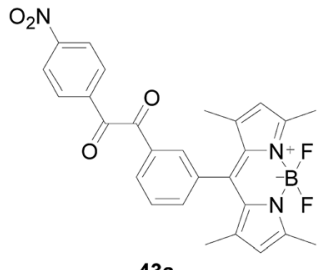

43a

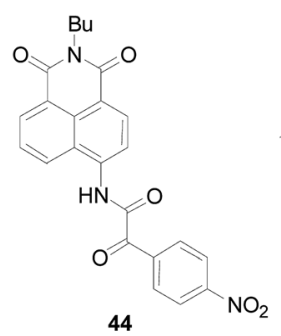

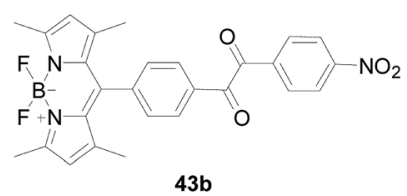

43b

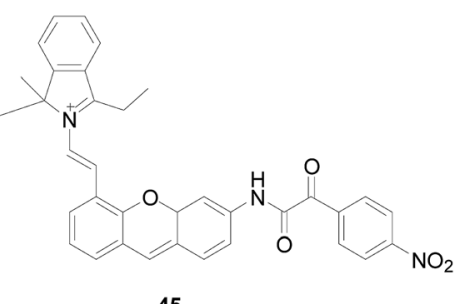

45
Fig. 26 Molecular structures of probes $43 a-b, 44$ and 45

$\mathrm{H}_{2} \mathrm{O}_{2}$ to increase the adsorption capacity and sensing efficiency, probe 43a exhibits a fast response $(30 \mathrm{~s})$ and high sensitivity (0.94 ppb) to $\mathrm{H}_{2} \mathrm{O}_{2}$ vapor, and has a high fluorescence quantum yield of $0.43-0.56$. Probe $43 \mathrm{a}$ is the first fluorescent probe could be successfully used for $\mathrm{H}_{2} \mathrm{O}_{2}$ vapor detection and has been used for the visual detection of $\mathrm{H}_{2} \mathrm{O}_{2}$ of vapor by naked-eye and fluorescence imaging in living cells. Almost at the same time, Sabrina Heng's team reported a probe ${ }^{\mathbf{1 0 1}}$ with the same structure as $\mathbf{4 3 b}$ and performed spectral analysis, selectivity and cell imaging experiments. The probe is highly selective for $\mathrm{H}_{2} \mathrm{O}_{2}$, and oocytes stained with probe showed a minor increase in fluorescence when treated with $\mathrm{H}_{2} \mathrm{O}_{2}$.

Zhang Xiaoling's group ${ }^{\mathbf{1 0 2}}$ published a ratio type fluorescent probe 44 (Fig. 26) for the targeted detection of $\mathrm{H}_{2} \mathrm{O}_{2}$ in the endoplasmic reticulum. The $\alpha$-ketoamide in the probe was converted to an amine after reaction with $\mathrm{H}_{2} \mathrm{O}_{2}$, the new fluorescence emission peak gradually increased at $540 \mathrm{~nm}$, and the peak at $465 \mathrm{~nm}$ gradually decreased. The probe 44 can quantitatively detected the content of $\mathrm{H}_{2} \mathrm{O}_{2}$ by the ratio method with highly selectivity, and eliminated the error caused by the probe concentration and environment. And realizes the detection of exogenous $\mathrm{H}_{2} \mathrm{O}_{2}$ in HeLa cells.

Using the same mechanism, Bo Tang's research group ${ }^{\mathbf{1 0 3}}$ developed a near-infrared fluorescent probe 45 (Fig. 26), which integration a unique reaction site $\alpha$-ketoamide into a hemicyanine fluorophore. Probe $\mathbf{4 5}$ is a fluorescence "off-on" probe regulated by an ICT mechanism. Upon reaction with $\mathrm{H}_{2} \mathrm{O}_{2}$, hemicyanine- $\mathrm{NH}_{2}$ was released and showed significant fluorescence enhancement attributing to the ICT process. Probe 45 has a high reaction rate and high specificity, and the fluorescence intensity at $704 \mathrm{~nm}$ in the fluorescence spectrum increases as the concentration of $\mathrm{H}_{2} \mathrm{O}_{2}$ increases, whereas other ROS or RNS no. The use of probe 45 confirmed the formation of $\mathrm{H}_{2} \mathrm{O}_{2}$ during ischemia-reperfusion injury at both cell organ levels.

In general, the above-mentioned benzil-responsive fluorescent $\mathrm{H}_{2} \mathrm{O}_{2}$ probe reacts more rapidly, and both used a nitro group as an electron-withdrawing group to enhance the reactivity of the probe. However, this type of ratio-type near-infrared probe is not mature enough, and there is room for further research.

\section{5. o-Benzenediol based fluorescent $\mathrm{H}_{2} \mathrm{O}_{2}$ probes}

The $o$-diphenolic hydroxyl group is also a good response group for $\mathrm{H}_{2} \mathrm{O}_{2}$.

Hankley's team ${ }^{\mathbf{1 0 4}}$ introduced the synthesis and biological applications of a novel $\mathrm{H}_{2} \mathrm{O}_{2}$ probe 46 (Fig. 27). The $o$-diphenolic hydroxyl in the probe structure reacted with $\mathrm{H}_{2} \mathrm{O}_{2}$ to oxidize to $o$-quinone, which was a fluorescence quenching reaction, and the fluorescence intensity at $630 \mathrm{~nm}$ gradually decreased with the colour change from blue to purple of solution. Only a small fluorescence response was observed in the emission spectrum except for physiologically relevant levels of $\mathrm{H}_{2} \mathrm{O}_{2}$. As the GSH in the solution added, the fluorescence was turn on. Therefore, this "on-off-on" type of probe can monitor intracellular $\mathrm{H}_{2} \mathrm{O}_{2}$ oxidative stress and thiol-reduction repair processes simply and directly, and has good permeability and specificity in cells, negligible background fluorescence and cells toxicity.

As a further study in this field, in 2017, Manoj Kumar and colleagues $^{\mathbf{1 0 5}}$ reported a lysosomal targeting $\mathrm{H}_{2} \mathrm{O}_{2}$ fluorescent probe 47 (Fig. 28), which comprised a catechol responsive group and a naphthalimide fluorophore. In that catechol can undergo PET effects to the naphthalimide core resulting in weak molecular fluorescence in aqueous solution. Upon addition of $\mathrm{H}_{2} \mathrm{O}_{2}$ to the aqueous solution of probe 47 , the PET effects were inhibited and the emission band at $537 \mathrm{~nm}$ was enhanced. There was no obviously fluorescent response to other ROS/RNS like NO, TBHP, $\cdot \mathrm{OH}$, and $\mathrm{OONO}^{-}$and bio-thiols like Cys, GSH and Hcy. The morpholino group in the probe 47 acted as a lysosomes-targeting group can be used for endogenous detection of $\mathrm{H}_{2} \mathrm{O}_{2}$ in living cell lysosomes, and can also be used to detect $\mathrm{H}_{2} \mathrm{O}_{2}$ in brain tissues and living nematodes.

\section{Enamine-based fluorescent probes for $\mathrm{H}_{2} \mathrm{O}_{2}$}

In 2018, Wang Peng's group ${ }^{\mathbf{1 0 6}}$ used $\mathrm{H}_{2} \mathrm{O}_{2}$ to promote the carbon-carbon double bond cleavage, and prepared a probe 48 (Fig. 29) with an enamine group as a reactive group. After the reaction of the compound 48 with $\mathrm{H}_{2} \mathrm{O}_{2}$, a peroxide intermediate formed, which is then converted to a stable amide with

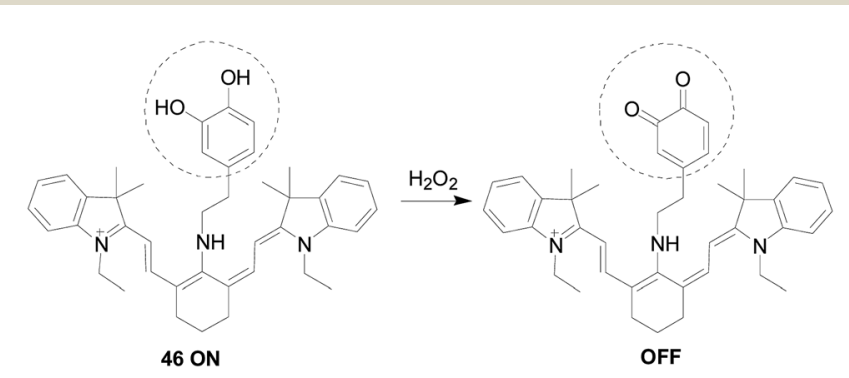

Fig. 27 Reaction mechanism of probe 46 with $\mathrm{H}_{2} \mathrm{O}_{2}$. 


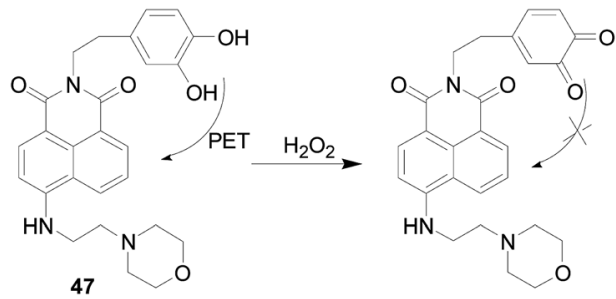

Fig. 28 Fluorescence response of probe 47 to $\mathrm{H}_{2} \mathrm{O}_{2}$.

blue fluorescence emission with good sensitivity. The response of probe 48 to $\mathrm{H}_{2} \mathrm{O}_{2}$ was nearly 10-30 times than that of control group and other interference factors, such as various amino acids (Met, Glu, Cys, GSH) and ROS (TBPH, $\mathrm{ClO}^{-}, \cdot \mathrm{OH}, \mathrm{NO}$, $\mathrm{ONOO}^{-}$). Properly designed probes have great potential to monitor $\mathrm{H}_{2} \mathrm{O}_{2}$ in cells, mouse liver sections and tumor tissues using single-photon and two-photon fluorescence imaging with low cytotoxicity.

\section{Other types probes for $\mathrm{H}_{2} \mathrm{O}_{2}$}

Yutaka Hitomi's team ${ }^{107}$ developed a metal-based probe 49 (Fig. 30), which produced a fluorescent response faster than an organic molecular-based fluorescent probe, showing significant fluorescence enhancement in 20 seconds. The Fe complex in this probe reacted rapidly with $\mathrm{H}_{2} \mathrm{O}_{2}$ to form a cationic amide group by three routes. Hydrolysis of the cationic amide group by an iron(III)-bound hydroxo group or an unbound water molecule finally gives resorufin and a hydrolyzed iron complex, $\left[\mathrm{Fe}^{\mathrm{III}}(3)\right]^{2+}$. Resorufin produces significant red fluorescence. The authors applied it to the detection of $\mathrm{H}_{2} \mathrm{O}_{2}$ produced during the enzymatic reaction. Since probe $\mathbf{4 9}$ may be hydrolyzed by amidate under cell culture conditions, which hinders its application to fluorescence imaging of intracellular $\mathrm{H}_{2} \mathrm{O}_{2}$. In order to fully enhance the stability of the metal complex $\mathrm{H}_{2} \mathrm{O}_{2}$ probe to visualize intracellular $\mathrm{H}_{2} \mathrm{O}_{2}$, the group developed a new iron complex-based probe $\mathbf{5 0}$ (ref. 108) (Fig. 30). The group employs the nonheme iron-based peroxidase mimetic $\mathrm{Fe}(\mathrm{III}) \mathrm{mpaq}$ (mpaq $=2$-[N-methyl- $N$-pyridin-2-ylmethyl $]$-amino- $N^{\prime}$ quinolin8-yl-acetamido) as a $\mathrm{H}_{2} \mathrm{O}_{2}$-responsive component, in which the iron complex reacts rapidly with $\mathrm{H}_{2} \mathrm{O}_{2}$ to form an oxidant substance that converts the closely appended $o$-alkyl resorufin moiety to resorufin. Probe $\mathbf{5 0}$ showed a strong enhancement in fluorescence intensity in response to $\mathrm{H}_{2} \mathrm{O}_{2}$, which was much

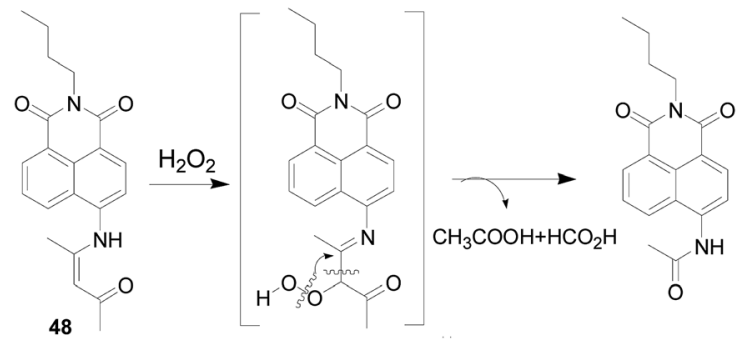

Fig. 29 Mechanism of probe 48 to $\mathrm{H}_{2} \mathrm{O}_{2}$.

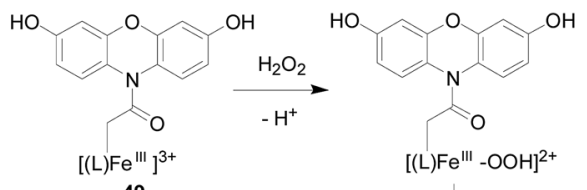

49

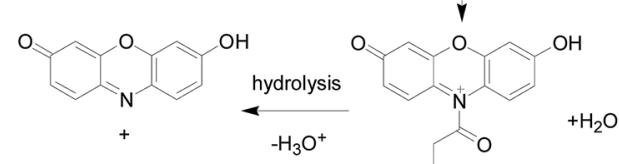

$\left[\mathrm{Fe}^{\text {III }}(3)\right]^{2+} \quad\left[(\mathrm{L}) \mathrm{Fe}^{\text {III }}-\mathrm{OH}\right]^{3+}$

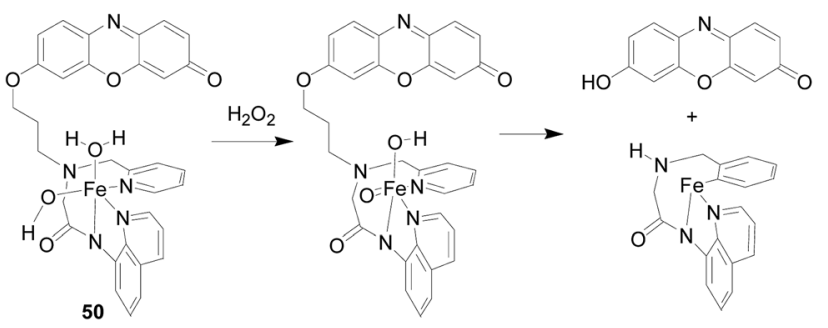

Fig. 30 Reaction scheme of 49 and 50 with $\mathrm{H}_{2} \mathrm{O}_{2}$.

stronger than other oxidants such as $\cdot \mathrm{OtBu}, \mathrm{O}_{2}{ }^{-}, \mathrm{NO}$ and $\mathrm{ClO}^{-}$. Experiments have shown that probe 50 is suitable for $\mathrm{H}_{2} \mathrm{O}_{2}$ imaging produced by EGF stimulation.

Youngmin You's team ${ }^{109}$ developed a new fluorescent probe 51 (Fig. 31) for $\mathrm{H}_{2} \mathrm{O}_{2}$ based on the cleavage of a paramagnetic $\mathrm{Fe}$ ionophore from a fluorophore. By dissociation of the $\mathrm{Fe}-$ ionophore, probes 51 reacts with $\mathrm{H}_{2} \mathrm{O}_{2}$ produces 2,7-dichlorofluorescein, rather than other oxidants derived from $\mathrm{H}_{2} \mathrm{O}_{2}$ (e.g., $\cdot \mathrm{OH}$ ). Almost no response was observed for $\mathrm{O}_{2}{ }^{-}, \mathrm{HOCl}, t-$ $\mathrm{BuOOH}, \mathrm{NO},{ }^{1} \mathrm{O}_{2}$, and only a limited increase in the fluorescence intensity was observed in the cases of $t-\mathrm{BuOOH}$ and $\cdot \mathrm{OH}$. Moreover, the probe $\mathbf{5 1}$ is suitable for live cell imaging and has the ability to detect intracellular $\mathrm{H}_{2} \mathrm{O}_{2}$ in lysosomes.

Xiaoqi Yu's research group ${ }^{110}$ designed and synthesized a "turn-on" type fluorescent probe $\mathbf{5 2}$ containing selenium. Under the action of $\mathrm{H}_{2} \mathrm{O}_{2}$, the selenium atom was oxidized to selenium oxide, and the effect of PET itself was inhibited,

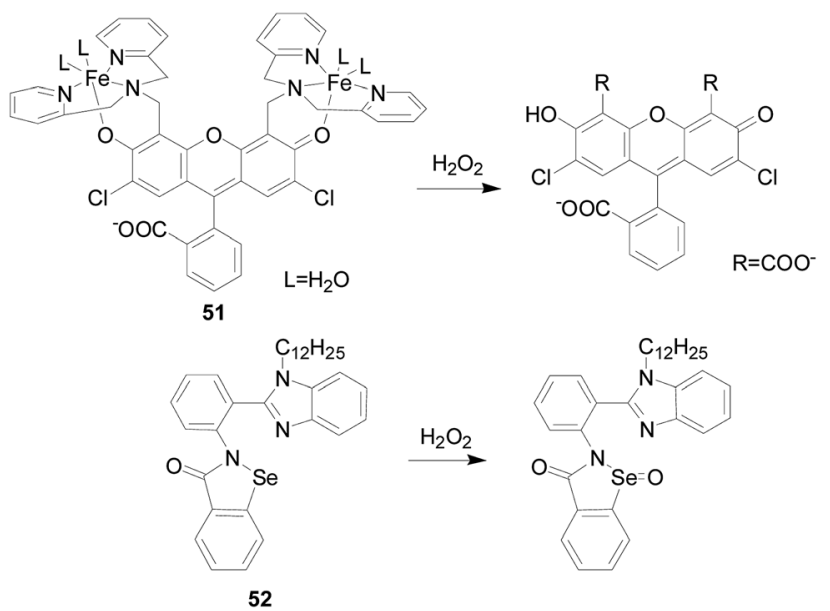

Fig. 31 Reaction mechanism of probes 51 and 52 with $\mathrm{H}_{2} \mathrm{O}_{2}$ respectively. 
forming aggregates and AIE-type fluorescence occurred. The fluorescence intensity of probe $\mathbf{5 2}$ was proportional to the $\mathrm{H}_{2} \mathrm{O}_{2}$ concentration, more than 110 -fold fluorescence enhancement was observed after treatment with $200 \mu \mathrm{M} \mathrm{H}_{2} \mathrm{O}_{2}$ for $1 \mathrm{~h}$ at ambient temperature. Other ROS/RNS, including $\mathrm{ClO}^{-}, \mathrm{TBPH}$, $\mathrm{ONOO}^{-}, \cdot \mathrm{OtBu}, \cdot \mathrm{OH},{ }^{1} \mathrm{O}_{2}$, and $\mathrm{O}_{2}{ }^{-}$, could not cause the fluorescence change of the probe $\mathbf{5 2}$.

\section{Concluding and outlook}

The production, decomposition and diffusion of hydrogen peroxide are unstable in different cells. It is important to develop a highly sensitive hydrogen peroxide probe for real-time in situ detection of $\mathrm{H}_{2} \mathrm{O}_{2}$ in cells or organisms. ${ }^{111}$ The development of fluorescent probes provides a versatile and valuable way of thinking about the processes behind many biological phenomena in living systems. Among the most $\mathrm{H}_{2} \mathrm{O}_{2}$ probes, the development of fluorescent probes is the most extensive because of their better biocompatibility and higher sensitivity.

This review summarizes several commonly used small molecule types of $\mathrm{H}_{2} \mathrm{O}_{2}$ fluorescent probes, such as based on aryl borate or boric acid, sulfonate, benzoyl and the like. These fluorescent probes are able to overcome the nature of hydrogen peroxide itself and have high sensitivity and specificity for $\mathrm{H}_{2} \mathrm{O}_{2}$. The probes developed in recent years combined with confocal microscopy and micro-spectral detection technology have been able to perform "real-time, visible, quantitative" detection of hydrogen peroxide in living cells and tissues. In spite of that, the development of probes requires further consideration of the following issues. Since the same recognition moiety that adapts to different fluorophores will exhibit specificity for different targets, an in-depth study can be performed based on the structure-reactivity relationship of the reported probes to derive intrinsic rules that guide the targeted design and synthesis of the probe. Although the detection of endogenous $\mathrm{H}_{2} \mathrm{O}_{2}$ in vivo can be obtained, the imaging depth is still limited due to the light penetrating ability and the stability of the probe. Due to the low background interference and weak photo-bleaching effects, ratiometric and TP-probes have great bio-imaging potential for $\mathrm{H}_{2} \mathrm{O}_{2}$ and can be used as sensing platforms, but this only helps solve some of the problems, not all. In general, these issues not only provide researchers with challenges, but also the opportunity to enter new research areas.

Therefore, in the development of the probe, considering the relatively low concentration in steady state of $\mathrm{H}_{2} \mathrm{O}_{2}$ in the body, it needs to be designed from both chemical and biological aspects. On the one hand, we need to find more reaction mechanisms (currently based on oxidation reactions). On the other hand, in addition to considering high selectivity and sensitivity, low auto-oxidation, high optical stability, low cytotoxicity, good solubility, cell permeability, and low interference of biological environmental substances need to be considered. In addition, since redox reactions are involved in the maintenance of normal function and health of cells, it is also a research focus of fluorescent probes to study redox probes of cellular redox biology by monitoring changes in reversible fluorescence over time.
In summary, the search for probes that better reflect the physiological and pathological functions of $\mathrm{H}_{2} \mathrm{O}_{2}$ in cells and organisms will be one of the important hotspots and difficult areas of current life science research. We believe that with the development and further integration of novel small molecule fluorescent probes in related fields such as pharmacy, medicine and life sciences, the physiological and pathological functions of $\mathrm{H}_{2} \mathrm{O}_{2}$ in biological systems will be better explained and understood. Hydrogen peroxide probes will have broader application prospects in the fields of pathophysiology, disease diagnosis and treatment.

\section{Conflicts of interest}

There are no conflicts to declare.

\section{Acknowledgements}

This work was supported by the National Natural Science Foundation of China (No. 21305079 and 21606147), the Academy of Science and Technology Project of Shandong Academy of Medical Sciences (No. 2017-55 and 2018-19), Key Projects of Industrial Science and Technology Plan in Qiannan Prefecture (2017) 11, project of Haixi Science and Technology Bureau of Qinghai Province 2017-Q4.

\section{Notes and references}

1 C. Nathan and A. Cunningham-Bussel, Nat. Rev. Immunol., 2013, 13, 349-361.

2 S. J. Dixon and B. R. Stockwell, Nat. Chem. Biol., 2014, 10, 917.

3 C. C. Winterbourn, Nat. Chem. Biol., 2008, 4, 278-286.

4 H. Wu, Q. Song, G. Ran, X. Lu and B. Xu, TrAC, Trends Anal. Chem., 2011, 30, 133-141.

5 F. L. Muller, M. S. Lustgarten, Y. Jang, A. Richardson and H. Van Remmen, Free Radical Biol. Med., 2007, 43, 477-503.

6 J. J. Hu, N. K. Wong, S. Ye, X. Chen, M. Y. Lu, A. Q. Zhao, Y. Guo, A. C. Ma, A. Y. Leung, J. Shen and D. Yang, J. Am. Chem. Soc., 2015, 137, 6837-6843.

7 A. A. Alfadda and R. Sallam, J. Biomed. Biotechnol., 2012, 2012, 936486.

8 T. F. Brewer, F. J. Garcia, C. S. Onak, K. S. Carroll and C. J. Chang, Annu. Rev. Biochem., 2015, 84, 765-790.

9 A. Kaur, M. A. Haghighatbin, C. F. Hogan and E. J. New, Chem. Commun., 2015, 51, 10510-10513.

10 L. A. Sena and N. S. Chandel, Mol. Cell, 2012, 48, 158-167.

11 C. C. Winterbourn, Biochim. Biophys. Acta, 2014, 1840, 730738.

12 A. Gomes, E. Fernandes and J. L. F. C. Lima, J. Biochem. Biophys. Methods, 2005, 65, 45-80.

13 P. D. Ray, B. W. Huang and Y. Tsuji, Cell. Signalling, 2012, 24, 981-990.

14 N. Kumar, V. Bhalla and M. Kumar, Coord. Chem. Rev., 2013, 257, 2335-2347. 
15 X. Sun, Q. Xu, G. Kim, S. E. Flower, J. P. Lowe, J. Yoon, J. S. Fossey, X. Qian, S. D. Bull and T. D. James, Chem. Sci., 2014, 5, 3368.

16 X. Zhou, Y. Kwon, G. Kim, J. H. Ryu and J. Yoon, Biosens. Bioelectron., 2015, 64, 285-291.

17 Z. Lou, P. Li and K. Han, Acc. Chem. Res., 2015, 48, 13581368.

18 K. Araki and K. Inaba, Antioxid. Redox Signaling, 2012, 16, 790-799.

19 B. Chance, H. Sies and A. Boveris, Physiol. Rev., 1979, 59, 527-605.

20 H. C. Dawkes and S. E. Phillips, Curr. Opin. Struct. Biol., 2001, 11, 666-673.

21 J.-J. P. Kim and R. Miura, Eur. J. Biochem., 2004, 271, 483493.

22 T. Finkel, Curr. Opin. Cell Biol., 2003, 15, 247-254.

23 J. R. Stone and S. Yang, Antioxid. Redox Signaling, 2006, 8, 243-270.

24 P. Niethammer, C. Grabher, A. T. Look and T. J. Mitchison, Nature, 2009, 459, 996-999.

25 C. Behl, J. B. Davis, F. Lesley and D. Schubert, Cell, 1994, 77, 817-827.

26 B. D'Autreaux and M. B. Toledano, Nat. Rev. Mol. Cell Biol., 2007, 8, 813-824.

27 J. R. Stone and S. Yang, Antioxid. Redox Signaling, 2006, 8, 243-270.

28 H. Ohshima, M. Tatemichi and T. Sawa, Arch. Biochem. Biophys., 2003, 417, 3-11.

29 K. J. Barnham, C. L. Masters and A. I. Bush, Nat. Rev. Drug Discovery, 2004, 3, 205-214.

30 A. M. Shah and K. M. Channon, Heart, 2004, 90, 485.

$31 \mathrm{H}$. Rath and E. Schönpflug, Bestimmung von Faserbegleitstoffen, 1960.

32 R. Brandt and A. S. Keston, Anal. Biochem., 1965, 11, 6-9.

33 S. L. Hempel, G. R. Buettner, Y. Q. O'Malley, D. A. Wessels and D. M. Flaherty, Free Radical Biol. Med., 1999, 27, 146159.

34 H. G. Kuivila and A. G. Armour, J. Am. Chem. Soc., 1957, 79, 5659-5662.

35 L. C. Lo and C. Y. Chu, Chem. Commun., 2003, 2728.

36 M. C. Y. Chang, A. Pralle, E. Y. Isacoff and C. J. Chang, J. Am. Chem. Soc., 2004, 126, 15392-15393.

37 A. E. Albers, V. S. Okreglak and C. J. Chang, J. Am. Chem. Soc., 2006, 128, 9640-9641.

38 E. W. Miller, O. Tulyathan, E. Y. Isacoff and C. J. Chang, Nat. Chem. Biol., 2007, 3, 263-267.

39 B. C. Dickinson and C. J. Chang, J. Am. Chem. Soc., 2008, 130, 9638-9639.

40 A. E. Albers, B. C. Dickinson, E. W. Miller and C. J. Chang, Bioorg. Med. Chem. Lett., 2008, 18, 5948-5950.

41 C. Y. Ang, S. Y. Tan, S. Wu, Q. Qu, M. F. E. Wong, Z. Luo, P.-Z. Li, S. Tamil Selvan and Y. Zhao, J. Mater. Chem. C, 2016, 4, 2761-2774.

42 J. Dong, Z. Zhao, R. Liu, H. Zhang, Y. Wu and X. Ba, RSC Adv., 2017, 7, 55067-55073.

43 L. Du, M. Li, S. Zheng and B. Wang, Tetrahedron Lett., 2008, 49, 3045-3048.
44 L. Du, N. Ni, M. Li and B. Wang, Tetrahedron Lett., 2010, 51, 1152-1154.

45 J. Xu, Q. Li, Y. Yue, Y. Guo and S. Shao, Biosens. Bioelectron., 2014, 56, 58-63.

46 J. Xu, Y. Zhang, H. Yu, X. Gao and S. Shao, Anal. Chem., 2016, 88, 1455-1461.

47 Y. Liu, J. Niu, J. Nie, F. Meng and W. Lin, New J. Chem., 2017, 41, 3320-3325.

48 J. Han, C. Chu, G. Cao, W. Mao, S. Wang, Z. Zhao, M. Gao, H. Ye and X. Xu, Bioorg. Chem., 2018, 81, 362-366.

49 Y. Chen, X. Shi, Z. Lu, X. Wang and Z. Wang, Anal. Chem., 2017, 89, 5278-5284.

50 J. Liu, J. Ren, X. Bao, W. Gao, C. Wu and Y. Zhao, Anal. Chem., 2016, 88, 5865-5870.

51 J. Liu, S. Zhou, J. Ren, C. Wu and Y. Zhao, Analyst, 2017, 142, 4522-4528.

52 W. Zhang, W. Liu, P. Li, F. Huang, H. Wang and B. Tang, Anal. Chem., 2015, 87, 9825-9828.

53 Z. Song, R. T. Kwok, D. Ding, H. Nie, J. W. Lam, B. Liu and B. Z. Tang, Chem. Commun., 2016, 52, 10076-10079.

54 J. Liu, C. Zhang, J. Dong, J. Zhu, C. Shen, G. Yang and X. Zhang, New J. Chem., 2017, 41, 4733-4737.

55 M. Ren, B. Deng, K. Zhou, X. Kong, J. Y. Wang and W. Lin, Anal. Chem., 2017, 89, 552-555.

56 X. Wang, Y. Huang, W. Lv, C. Li, W. Zeng, Y. Zhang and X. Feng, Anal. Methods, 2017, 9, 1872-1875.

57 F. Dai, F. Jin, Y. Long, X. Jin and B. Zhou, Free Radical Res., 2018, 1-151.

58 Z. Zhou, Y. Li, W. Su, B. Gu, H. Xu, C. Wu, P. Yin, H. Li and Y. Zhang, Sens. Actuators, B, 2019, 280, 120-128.

59 L. Zhou, H. Ding, W. Zhao and S. Hu, Spectrochim. Acta, Part A, 2019, 206, 529-534.

60 X. Liu, L. He, L. Yang, Y. Geng, L. Yang and X. Song, Sens. Actuators, B, 2018, 259, 803-808.

61 X. Liu, H. Tian, L. Yang, Y. Su, M. Guo and X. Song, Sens. Actuators, B, 2018, 255, 1160-1165.

62 J. Wang, W. Zhu, G. Niu, G. Jiang, Q. Chen, P. Gao, Y. Li, G. Zhang, X. Fan and B. Z. Tang, Chem. Commun., 2018, 54, 13957-13960.

63 F. Xu, W. Tang, S. Kang, J. Song and X. Duan, Dyes Pigm., 2018, 153, 61-66.

64 L. Yang, J. Y. Niu, R. Sun, Y. J. Xu and J. F. Ge, Analyst, 2018, 143, 1813-1819.

65 N. Zhang, B. Dong, X. Kong, C. Wang, W. Song and W. Lin, J. Fluoresc., 2018, 28, 681-687.

66 X. Liang, X. Xu, D. Qiao, Z. Yin and L. Shang, Chem. - Asian J., 2017, 12, 3187-3194.

67 F. Xu, H. Li, Q. Yao, J. Fan, J. Wang and X. Peng, J. Mater. Chem. B, 2016, 4, 7363-7367.

68 H. Xiao, P. Li, X. Hu, X. Shi, W. Zhang and B. Tang, Chem. Sci., 2016, 7, 6153-6159.

69 Y. Shen, F. Yan, X. Huang, X. Zhang, Y. Zhang, C. Zhang, J. Jin, H. Li and S. Yao, RSC Adv., 2016, 6, 88096-88103.

70 J. Shanmugapriya, K. Rajaguru, G. Sivaraman, S. Muthusubramanian and N. Bhuvanesh, RSC Adv., 2016, 6, 85838-85843. 
71 C. Chung, D. Srikun, C. S. Lim, C. J. Chang and B. R. Cho, Chem. Commun., 2011, 47, 9618-9620.

72 M. Ren, B. Deng, J. Y. Wang, X. Kong, Z. R. Liu, K. Zhou, L. He and W. Lin, Biosens. Bioelectron., 2016, 79, 237-243.

73 Q. Ma, X. li, J. Zhang, X. Zhu, L. Zhou and H. Liu, Anal. Methods, 2017, 9, 4558-4565.

74 H. Li, Q. Yao, J. Fan, J. Du, J. Wang and X. Peng, Biosens. Bioelectron., 2017, 94, 536-543.

75 G. Masanta, C. H. Heo, C. S. Lim, S. K. Bae, B. R. Cho and H. M. Kim, Chem. Commun., 2012, 48, 3518-3520.

76 C. S. Lim, M. K. Cho, M. Y. Park and H. M. Kim, ChemistryOpen, 2018, 7, 53-56.

77 Y. Lu, X. Shi, W. Fan, C. A. Black, Z. Lu and C. Fan, Spectrochim. Acta, Part A, 2018, 190, 353-359.

78 M. Kumar, N. Kumar, V. Bhalla, P. R. Sharma and Y. Qurishi, Chem. Commun., 2012, 48, 4719-4721.

79 D. Srikun, E. W. Miller, D. W. Domaille and C. J. Chang, J. Am. Chem. Soc., 2008, 130, 4596-4597.

80 G. Wu, F. Zeng, C. Yu, S. Wu and W. Li, J. Mater. Chem. B, 2014, 2, 8528-8537.

81 S.-L. Zhong, J. Zhang, Q. Hu, W.-X. Chen, T.-F. Ma and J.-H. Zhao, Asian Pac. J. Cancer Prev., 2014, 20, 2254.

82 N. Velusamy, N. Thirumalaivasan, K. N. Bobba, A. Podder, S. P. Wu and S. Bhuniya, J. Photochem. Photobiol., B, 2018, 191, 99-106.

83 L. He, X. Liu, Y. Zhang, L. Yang, Q. Fang, Y. Geng, W. Chen and X. Song, Sens. Actuators, B, 2018, 276, 247-253.

84 L. Tang, M. Tian, H. Chen, X. Yan, K. Zhong and Y. Bian, Dyes Pigm., 2018, 158, 482-489.

85 J. Hou, M. Qian, H. Zhao, Y. Li, Y. Liao, G. Han, Z. Xu, F. Wang, Y. Song and Y. Liu, Anal. Chim. Acta, 2018, 1024, 169-176.

86 K. Xu, L. He, X. Yang, Y. Yang and W. Lin, Analyst, 2018, 143, 3555-3559.

87 Y. Shen, X. Zhang, Y. Zhang, Y. Wu, C. Zhang, Y. Chen, J. Jin and H. Li, Sens. Actuators, B, 2018, 255, 42-48.

88 X. Lu, M. Zhao, P. Chen, Q. Fan, W. Wang and W. Huang, J. Mater. Chem. B, 2018, 6, 4531-4538.

89 A. Sikora, J. Zielonka, M. Lopez, J. Joseph and B. Kalyanaraman, Free Radical Biol. Med., 2009, 47, 14011407.

90 J. Zielonka, A. Sikora, M. Hardy, J. Joseph, B. P. Dranka and B. Kalyanaraman, Chem. Res. Toxicol., 2012, 25, 1793-1799.

91 J. Zhou, Y. Li, J. Shen, Q. Li, R. Wang, Y. Xu and X. Qian, RSC Adv., 2014, 4, 51589-51592.

92 H. Maeda, Y. Fukuyasu, S. Yoshida, M. Fukuda, K. Saeki, H. Matsuno, Y. Yamauchi, K. Yoshida, K. Hirata and
K. Miyamoto, Angew. Chem., Int. Ed. Engl., 2004, 43, 23892391.

93 K. Xu, B. Tang, H. Huang, G. Yang, Z. Chen, P. Li and L. An, Chem. Commun., 2005, 5974-5976.

94 K. Xu, F. Liu, H. Wang, S. Wang, L. Wang and B. Tang, Sci. China, Ser. B: Chem., 2009, 52, 734-740.

95 J. Heo, C.-K. Lim, Y. Kim, H.-J. Cho, Y.-D. Lee, J.-h. Maeng, D.-R. Ahn, S. Lee, J. Bang, S. Y. Park and S. Kim, Chem. Commun., 2016, 52, 1131-1134.

96 H. Guo, G. Chen, M. Gao, R. Wang, Y. Liu and F. Yu, Anal. Chem., 2019, 91, 1203-1210.

97 Y. Sawaki and C. S. Foote, J. Am. Chem. Soc., 1979, 101(21), 6292-6296.

98 M. Abo, Y. Urano, K. Hanaoka, T. Terai, T. Komatsu and T. Nagano, J. Am. Chem. Soc., 2011, 133, 10629-10637.

99 M. Abo, R. Minakami, K. Miyano, M. Kamiya, T. Nagano, Y. Urano and H. Sumimoto, Anal. Chem., 2014, 86, 59835990.

100 B. Li, J.-B. Chen, Y. Xiong, X. Yang, C. Zhao and J. Sun, Sens. Actuators, B, 2018, 268, 475-484.

101 M. S. Purdey, H. J. McLennan, M. L. Sutton-McDowall, D. W. Drumm, X. Zhang, P. K. Capon, S. Heng, J. G. Thompson and A. D. Abell, Sens. Actuators, B, 2018, 262, 750-757.

102 C. Gao, Y. Tian, R. Zhang, J. Jing and X. Zhang, Anal. Chem., 2017, 89, 12945-12950.

103 X. Xie, X. Yang, T. Wu, Y. Li, M. Li, Q. Tan, X. Wang and B. Tang, Anal. Chem., 2016, 88, 8019-8025.

104 F. Yu, P. Li, P. Song, B. Wang, J. Zhao and K. Han, Chem. Commun., 2012, 48, 4980-4982.

105 S. I. Reja, M. Gupta, N. Gupta, V. Bhalla, P. Ohri, G. Kaur and M. Kumar, Chem. Commun., 2017, 53, 3701-3704.

106 N. Li, J. Huang, Q. Wang, Y. Gu and P. Wang, Sens. Actuators, B, 2018, 254, 411-416.

107 Y. Hitomi, T. Takeyasu, T. Funabiki and M. Kodera, Anal. Chem., 2011, 83, 9213-9216.

108 Y. Hitomi, T. Takeyasu and M. Kodera, Chem. Commun., 2013, 49, 9929-9931.

109 D. Song, J. M. Lim, S. Cho, S.-J. Park, J. Cho, D. Kang, S. G. Rhee, Y. You and W. Nam, Chem. Commun., 2012, 48, 5449-5451.

110 Y. X. Liao, K. Li, M. Y. Wu, T. Wu and X. Q. Yu, Org. Biomol. Chem., 2014, 12, 3004-3008.

111 H. Guo, H. Aleyasin, B. C. Dickinson, R. E. Haskew-Layton and R. R. Ratan, Cell \& Bioscience, 2014, 4, 64. 